CAROLINE ARANTES MAGALHÃES CASTILHONE

\title{
ENTEROHEMOLISINA DE ESCHERICHIA COLI \\ ENTEROPATOGÊNICA ATÍPICA: NOVAS \\ CARACTERÍSTICAS FENOTÍPICAS
}

Dissertação de Mestrado apresentada ao Instituto de Ciências Biomédicas da Universidade de São Paulo, para obtenção do Título de Mestre em Ciências (Microbiologia). 


\section{ENTEROHEMOLISINA DE ESCHERICHIA COLI \\ ENTEROPATOGÊNICA ATÍPICA: NOVAS \\ CARACTERÍSTICAS FENOTÍPICAS}

Dissertação de Mestrado apresentada ao Instituto de Ciências Biomédicas da Universidade de São Paulo, para obtenção do Título de Mestre em Ciências.

Área de concentração: Microbiologia

Orientador:

Profa. Dra. Roxane Maria Fontes Piazza 
Aos meus pais pelo exemplo de vida, especialmente à minha mãe que em todos os momentos da minha vida foi minha amiga, meu pai, minha irmã e conselheira.

Ao meu querido e amado Junior obrigada por me amar, por me ouvir e por sempre tentar me agradar.

Ao meu maior tesouro, minha filha Beatriz, por me fazer sentir o maior amor de todos. 


\section{AGRADECIMENTOS}

Agradecer a todos que ajudaram a construir esta Dissertação não é tarefa fácil. Então, a meus amigos e familiares que, de uma forma ou de outra, contribuíram com sua amizade, carinho e paciência, gostaria de expressar minha profunda gratidão. Em especial à Dra. Roxane Maria Fontes Piazza, minha querida orientadora, pela oportunidade de realizar este trabalho, por todo tempo a mim dedicado, pelo carinho e compreensão. Aos pesquisadores do Laboratório de Bacteriologia, que com suas experiências contribuíram de forma significativa para a realização deste trabalho.

Às colaboradoras diretas desse trabalho Doutoras Ângela Silva Barbosa e Isabel Correia Batista, peças chaves na finalização desta Dissertação.

Aos amigos de bancada, Letícia Barbosa Rocha, Caroline Menezes, Júlia Nara, Márcio Menezes, Fernanda Oliveira e Christiane Ozaki pela amizade e pela alegria de trabalharmos juntos. À amiga Sarita Schneider Rossato, pelas colaborações nos experimentos e apoio sem os quais muito desse trabalho não seria possível.

Aos funcionários e técnicos do Laboratório de Bacteriologia pelo carinho, atenção e disponibilidade em sempre auxiliar.

Aos funcionários do Departamento de Pós-Graduação em Microbiologia, por seus préstimos, amizade, dedicação e gentileza no atendimento.

A todos que de forma direta ou indireta contribuíram para a realização e finalização deste trabalho. Meus sinceros agradecimentos. 
"Cada um cumpre o destino que the cumpre, E deseja o destino que deseja, Nem deseja o que cumpre. Como as pedras na orla dos canteiros. O Fado nos dispõe, e ali ficamos, Que a Sorte nos fez postos Onde havemos de sê-lo. $\mathcal{N}$ ão tenhamos melhor conhecimento Do que nos coube que de que nos coube. Cumpramos o que somos. Nada mais nos é dado."

Ricardo Reis 


\section{RESUMO}

MAGALHÃES, C. A. Enterohemolisina de Escherichia coli enteropatogênica atípica: novas características fenotípicas. 2007. 71 f. Dissertação (Mestrado em Microbiologia) - Instituto de Ciências Biomédicas, Universidade de São Paulo, São Paulo, 2007.

EPEC atípicas (EPECa) são isoladas de surtos diarréicos em crianças, adultos e animais em países industrializados e em desenvolvimento. Hemolisinas são toxinas que atuam sobre a membrana de eritrócitos e de diversos tipos celulares. Tal grupo de toxinas é reconhecido como importante fator de virulência envolvido na patogênese bacteriana, por isso o objetivo foi avaliar a expressão de enterohemolisina em isolados de EPECa e analisar características fenotípicas como interferência do meio de cultivo e adesão a componentes de matriz extracelular. Observou-se prevalência de $5,4 \%$ de isolados enterohemolíticos, e variações na expressão da toxina foram associadas à concentrações de lactose e caseína nos meios de cultivo. Além disso, verificouse forte associação entre produção de enterohemolisina e ligação à fibronectina celular.

Palavras-chave: Escherichia coli enteropatogênica atípica, enterohemolisina, expressão toxigênica, fibronectina celular. 


\begin{abstract}
MAGALHÃES, C. A. Atypical enteropathogenic Escherichia coli enterohemolysin: new phenotypical characteristics. 2007. 71 f Dissertação (Mestrado em Microbiologia) - Instituto de Ciências Biomédicas, Universidade de São Paulo, São Paulo, 2007.

Atypical EPEC (aEPEC) are isolated from diarrheal outbreaks in children, adults and animals in industrialized and developing countries. Hemolysins are toxins that act on the red cell membrane and various cell types. This group of toxins is recognized as an important virulence factor involved in the bacterial pathogenesis. The aim of this study was the evaluation of the enterohemolysin expression in aEPEC isolates as interference of the culture media and adhesion to components of extracellular matrix. The prevalence of enterohemolytic isolates was $5.4 \%$, and variations in toxin expression were associated with lactose and casein concentrations in culture media. Moreover, it was found association between production of enterohemolysin and adhesion to cellular fibronectin.
\end{abstract}

Key-words: Atypical enteropathogenic Escherichia coli, enterohemolysin, toxin expression, cellular fibronectin. 


\section{LISTA DE FIGURAS}

Figura 1. Eletroforese em gel de agarose $1 \%$ dos produtos de PCR para o gene ehxA dos isolados 1. 714, 2.1224, 3. 1887, 4. 2923, 5. 2991, 6. 2103, 7. 2117, 8. 2459, 9. 2775, 10. 3160, 11. 2062, 12. 4192, 13. água e 14. C3888. O gel foi corado em solução de 0,5 $\mu \mathrm{g} / \mathrm{mL}$ de brometo de etídio e visualizado em luz UV.

Figura 2. Figura representativa do ensaio hemolítico realizado em placas de ágar sangue de carneiro quando pré culltivados em meio Mínimo: 1. 2459 (O26:H11); 2. 1887 (O111:H38), 3. 2062 (O171:H48), 4. $4192(\mathrm{O} 11: \mathrm{H} 25)$, 5. $268(\mathrm{O} 49: \mathrm{H} 6), 6 . \mathrm{C} 3888$ (O26:H--).

Figura 3. Figura comparativa do ensaio hemolítico realizado em placas de ágar sangue dos isolados quando expressaram perfil hemolítico e não hemolítico: 1 e 2. 2062, 3 e 4. 4192; 5 e 6. 300, 7 e 8. 2034; 9 e 10. 4013, 11. C3888 e 12. 268

Figura 4. Perfil hemolítico do isolado 3160 cultivado em meio Mínimo: 1. $0,15 \%$, 2. $1,5 \%$ e 3 . $15 \%$ de caseína. Perfil hemolítico dos isolados: 4. 4192 (MM 15\%), 5. 300 (MM 0,15\%), 6. 300 (MM 1,5\%), 7. 2034 (MM 0,15\%).

Figura 5. Medida da quantidade de hemoglobina livre por meio da absorbância a $540 \mathrm{~nm}$ das suspensões de eritrócitos em diferentes concentrações incubadas V/V com água destilada por $1 \mathrm{~h}$ a $37^{\circ} \mathrm{C}$.

Figura 6. Quantidade de hemoglobina liberada medida por absorbância a $540 \mathrm{~nm}$ para os isolados controles de a-hemolisina (U4-41) e enterohemolisina (C3888) nas frações de sobrenadante (s) e precipitado $(p)$.

Figura 7. Ensaio de hemólise líquida representativa da liberação de hemoglobina provocada pelos isolados medida através da absorbância a $540 \mathrm{~nm}$. Isolados 268, 2103, 2459, 2775 e C3888 (EHly+) quando pré-cultivados em TSB (vermelho), meio mínimo (azul) e meio de Evans (verde) e os controles água e salina 0,15 $M$ (magenta). 
Figura 8. Quantidade de hemoglobina liberada medida por absorbância a $540 \mathrm{~nm}$ para os isolados enterohemolíticos 2103, 2459, 2775 e C3888 (EHly+), para o isolado negativo 268 e para o isolado $\alpha-$ hemolítico (U4-41) testados em TSB com glicose $2 \%$ (vermelho) ou lactose $2 \%$ (azul).

Figura 9. Perfil hemolítico do isolado C3888: 1. colônia bacteriana, 2. sobrenadante de cultivo, 3. precipitado rompido.

Figura 10. Reatividade das membranas de nitrocelulose contendo frações protéicas dos sobrenadantes bacterianos dos isolados: 1. C3888, 2. 268. As membranas foram incubadas com (A) soro imune não adsorvido e (B) soro imune adsorvido diluídos em 1:1.000 seguida da incubação com soro de cabra anti-rato conjugado a peroxidase.

Figura 11. Placa de ELISA sensibilizada com $100 \mu \mathrm{L}$ de sobrenadante ou precipitado ou bactérias fixadas dos isolados controles: produtor de enterohemolisina (C3888) e não produtor (268). Foram incubadas com soro imune em diversas diluições e soro de cabra anti-rato conjugado a peroxidase (1:10.000). Como solução cromógena foi utilizado OPD $+\mathrm{H}_{2} \mathrm{O}_{2}$ e leitura realizada a $492 \mathrm{~nm}$.

Figura 12. Placa de ELISA sensibilizada com os isolados bacterianos fixados com paraformaldeído. $\mathrm{O}$ isolado produtor de

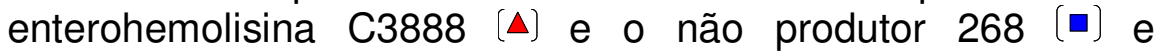
incubadas com soro imune nas diluições (A) 1:50, (B) 1:100 e (C) 1:200 respectivamente e soro de cabra anti-rato conjugado a peroxidase (1:10.000). Como solução cromógena foi utilizado $\mathrm{OPD}+\mathrm{H}_{2} \mathrm{O}_{2}$ e leitura realizada a $492 \mathrm{~nm}$.

Figura 13. Placa de ELISA sensibilizada com $100 \mu \mathrm{L}$ de sobrenadante dos isolados bacterianos produtor de enterohemolisina C3888 $(\Delta)$ e não produtor 268 ( incubadas com soro imune em nas diluições (A) 1:50, (B) 1:100 e (C) 1:200 e soro de cabra antirato conjugado a peroxidase (1:10.000). Como solução cromógena foi utilizado OPD $+\mathrm{H}_{2} \mathrm{O}_{2}$ e leitura realizada a 492 $\mathrm{nm}$. 
Figura 14. Placa de ELISA sensibilizada com sobrenadantes dos isolados bacterianos $(100 \mu \mathrm{L})$ produtores de enterohemolisina (A) e não produtores $(\mathbf{m}$ e incubadas com soro imune $(1: 200)$ e soro de cabra anti-rato conjugado a peroxidase (1:10.000). Como solução cromógena foi utilizado OPD $+\mathrm{H}_{2} \mathrm{O}_{2}$ e leitura realizada a $492 \mathrm{~nm}$.

Figura 15. Placa de ELISA sensibilizada com sobrenadantes dos isolados bacterianos (A) 2062, (B) 4192 cultivados em TSB em diferentes concentrações de glicose (G) ou lactose (L) e incubadas com soro imune (1:200) e soro de cabra anti-rato conjugado a peroxidase (1:10.000). Como solução cromógena foi utilizado OPD $+\mathrm{H}_{2} \mathrm{O}_{2}$ e leitura realizada a $492 \mathrm{~nm}$

Figura 16.Placa de ELISA sensibilizada com fibronectina celular incubadas com $20 \mu \mathrm{g}$ de sobrenadante concentrado dos isolados bacterianos produtores de enterohemolisina $(\mathbf{\Delta})$ e não produtores (-) e seguida da reação com soro imune (1:5.000) e soro de cabra anti-rato conjugado a peroxidase $(1: 10.000)$. Como solução cromógena foi utilizado OPD $+\mathrm{H}_{2} \mathrm{O}_{2}$ e leitura realizada a $492 \mathrm{~nm}$. 


\section{LISTA DE TABELAS}

Tabela 1. Composição dos principais meios de cultivo utilizados....... 29

Tabela 2. Iniciadores................................................................. 30

Tabela 3. Perfil hemolítico dos isolados de EPECa............................. 38

Tabela 4. Perfil hemolítico dos isolados em diferentes condições de pré-cultivo

Tabela 5. Perfil hemolítico dos isolados de EPECa em

meios modificados.

Tabela 6. Perfil hemolítico dos isolados de EPECa em meio

mínimo modificado. .45

Tabela 7. Adesão dos isolados de EPECa a componentes de matriz extracelular. .56 


\section{SUMÁRIO}

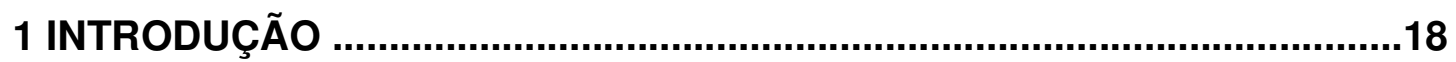

2 OBJETIVO

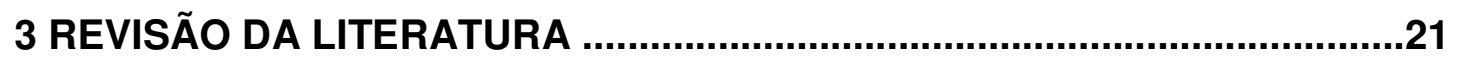

3.1 Epidemiologia da diarréia causada por Escherichia coli

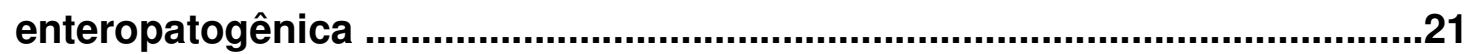

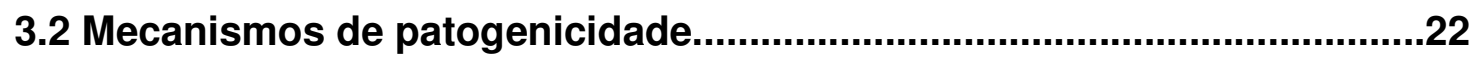

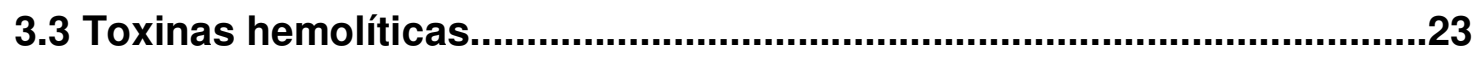

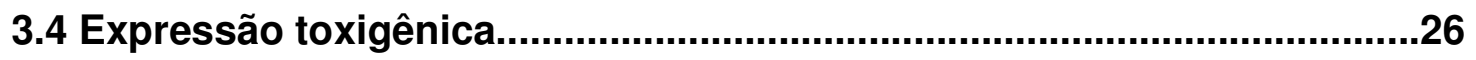

3.5 Adesão de proteínas bacterianas à matriz extra celular...........................27

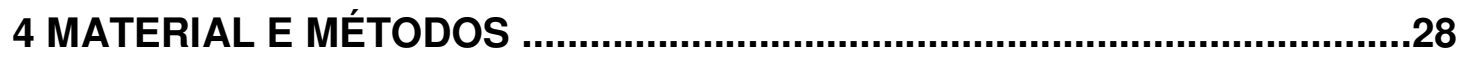

4.1 Isolados bacterianos e preparo de sobrenadantes................................28

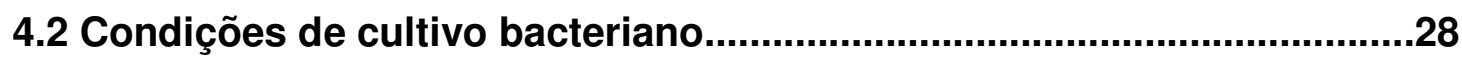

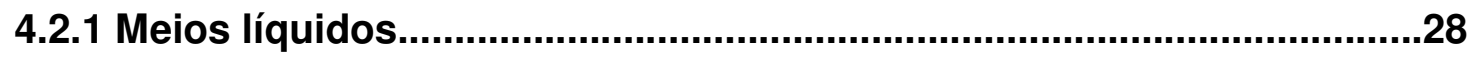

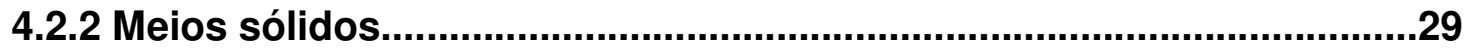

4.3 Pesquisa de hemolisinas em isolados de EPEC atípicas........................30

4.3.1 Reação de polimerase em cadeia (PCR)..............................................30

4.3.2 Ensaio de hemólise em ágar ............................................................30

4.3.3 Ensaio de hemólise em meio líquido......................................................31

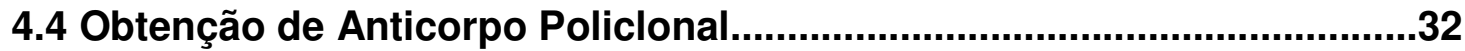

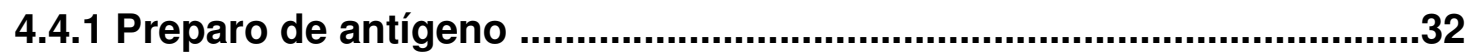

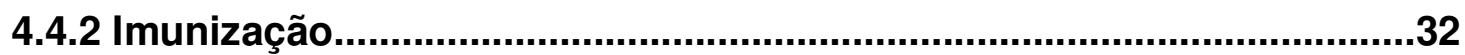

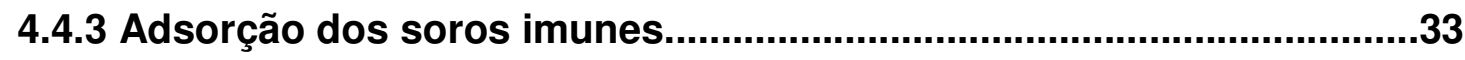

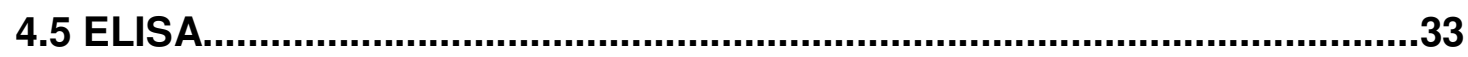

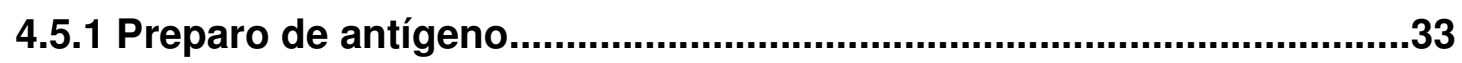


4.5.2. Padronização

4.5.3 Ensaios de ELISA para diferenciação de amostras produtoras e não produtoras de EHly .35

4.6 SDS/PAGE e Immunoblotting. .35

4.7 Ensaio de adesão das proteínas secretadas a componentes de matriz extracelular.

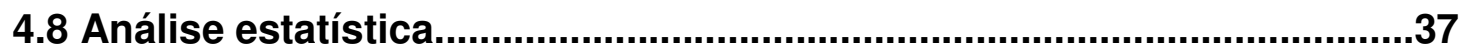

5 RESULTADOS ..................................................................................38

5.1 Identificação dos isolados enterohemolíticos......................................38

5.2 Detecção do gene ehxA por Reação de Polimerização em Cadeia (PCR).

5.3 Influência dos meios de cultivo na atividade hemolítica dos isolados.

5.4 Avaliação da interferência de componentes dos meios de cultivo na expressão toxigênica avaliada por hemólise em placa de ágar sangue de carneiro

5.5 Método quantitativo da expressão de enterohemolisina. .46

5.5.1 Padronização dos ensaios de hemólise líquida. .46

5.5.2 Avaliação da expressão de enterohemolisina nos diferentes meios de cultivo.

5.5.3 Interferência da lactose na atividade hemolítica. 
5.6 Produção de anticorpo policlonal.....................................................49

5.7 Padronização de ensaio imunoenzimático para diferenciação entre isolados hemolíticos e não hemolíticos. .51

5.8 Avaliação da interferência de componentes dos meios de cultivo na expressão toxigênica avaliada por ensaio imunoenzimático......................53

5.9 Inibição da atividade hemolítica pelo soro policlonal............................55

5.10 Associação dos isolados enterohemolíticos a componentes de Matriz Extracelular........................................................................................55

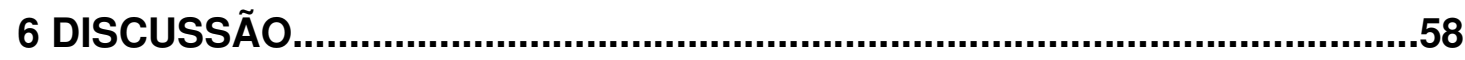

REFERÊNCIAS BIBLIOGRÁFICAS ..........................................................64 
CAROLINE ARANTES MAGALHÃES CASTILHONE

ENTEROHEMOLISINA DE ESCHERICHIA COLI

ENTEROPATOGÊNICA ATÍPICA: NOVAS

CARACTERÍSTICAS FENOTÍPICAS 


\section{INTRODUÇÃO}

Escherichia coli é um bacilo Gram negativo que pertence à família Enterobacteriaceae constituinte da microbiota dos animais homeotérmicos e coloniza o trato gastrointestinal destes logo após o nascimento. Apesar deste fato, algumas de suas linhagens são responsáveis por doenças como diarréia, infecções do trato urinário, bacteremia e meningite neonatal em humanos ou animais. Isolados de E. coli patogênicos podem ser diferenciados dos não patogênicos pela presença de fatores de virulência como os relacionados à colonização e adesão, invasão, moléculas de superfície, aparatos de transporte e secreção, moléculas secretadas, entre outros (FINLAY et al., 1997).

Isolados de Escherichia coli diarreiogênica são usualmente classificados em seis diferentes categorias de acordo com mecanismos de virulência específicos, as síndromes clínicas que causam, os sorotipos $\mathrm{O}: \mathrm{H}$, os aspectos epidemiológicos e os tipos de interação com linhagens celulares in vitro em: $E$. coli enteropatogênica (EPEC), E. coli produtora da toxina de Shiga (STEC), E. coli enterotoxigênica (ETEC), E. coli enteroagregativa (EAEC), E. coli enteroinvasora (EIEC) e E. coli difusamente aderente (DAEC) (NATARO, KAPER, 1998). Embora essa classificação continue sendo usada pela maioria dos autores, já se torna evidente que algumas categorias incluem patotipos bastante diferentes. Desta forma, as EPEC e EAEC foram subdivididas em típicas e atípicas e as EHEC passaram a constituir uma subcategoria de E. coli produtora da toxina de Shiga (STEC) (KAPER et al., 2004).

Nos diferentes patotipos de E. coli diarreiogênica tanto as toxinas, como as proteínas efetoras são mais diversas do que as estruturas da superfície bacteriana e estão envolvidas em diversos processos celulares como o aumento da concentração de mensageiros intracelulares, como AMP cíclico, GMP cíclico e $\mathrm{Ca}^{2+}$ que levam à secreção anormal de íons, bem como a quebra 
do RNA ribossomal, interrompendo assim, a síntese de proteínas levando à intoxicação das células epiteliais e endoteliais (FASANO, 1990).

A expressão de fatores de virulência pode ser bastante variada em função da composição e concentração de nutrientes no meio em que a bactéria é cultivada, da densidade celular, da temperatura entre outras variáveis. Tais fatores com expressão diferencial estão geralmente envolvidos em processos como sistemas de secreção, metabolismo de membrana e parede celular, sistema de captação de ferro, metabolismo de açúcares, transdução de sinais, metabolismo de flagelo, formação de biofilme e adesão, metabolismo de ácidos nucléicos, transportadores de membrana, metabolismo energético e resposta a estresse ambiental.

Algumas proteínas bacterianas inserem-se na membrana plasmática da célula hospedeira e causam a formação de canais ou poros que provocam a lise da célula. Há várias famílias de toxinas formadoras de poros tais como a grande família de citolisinas encontradas em muitos organismos Gram-positivos e a grande família RTX cujas toxinas são encontradas em muitos patógenos Gram-negativos. Nos patógenos em que as hemolisinas são fundamentais na patogênese é avaliada comumente a adesão ou a interação da molécula toxigênica com componentes do tecido vascular e/ou elementos sanguíneos. A ligação da bactéria a um ou mais componentes teciduais como colágeno I e IV, laminina, fibronectinas celular e plasmática seriam indícios de que essas moléculas estariam sendo usadas como substrato de adesão e colonização do hospedeiro pela bactéria patogênica (LOWRANCE et al., 1988).

Dentre as toxinas descritas, a enterohemolisisna tem sido relacionada a patogenicidade de STEC e alguns trabalhos têm sugerido que as EPEC atípicas sejam talvez mais próximas a esse patotipo que das EPEC típicas. Nesse contexto surgiram os objetivos desse trabalho que foi a expressão dessa toxina em diferentes condições de cultivo bacteriano e sua ligação a componentes de matriz extracelular. 


\section{OBJETIVOS}

Avaliar a expressão de enterohemolisina em isolados de EPEC atípica de diferentes sorotipos e a sua adesão a componentes de matriz extracelular. 


\section{REVISÃO DA LITERATURA}

\subsection{Epidemiologia da diarréia causada por Escherichia coli enteropatogênica}

Dentre as EPEC, as típicas (EPECt) são responsáveis pela diarréia aguda em crianças de até um ano de idade em países em desenvolvimento. Por outro lado, as atípicas (EPECa) são responsáveis pela diarréia aguda em crianças e adultos tanto em países em desenvolvimento como em países industrializados. Diferentemente, das EPECt, que têm somente o homem como hospedeiro, as EPECa atingem ou infectam tanto homens como animais e desde a década de 60 têm substituído as EPEC típicas nos países industrializados e, nos países em desenvolvimento, vêm aparecendo como um patógeno emergente (SCALETSKY et al.; 2002, TRABULSI et al.; 2002, BARRETO et al., 2005; FRANZOLIN et al., 2005; BUERIS et al., 2007; ARAUJO et al., 2007).

A maioria dos estudos investigativos realizados em crianças com diarréia ou saudáveis como grupo controle mostrou uma maior prevalência de EPECa entre pessoas com quadro diarréico quando comparado ao grupo controle. Tal prevalência tem sido um argumento bastante consistente para considerar-se EPECa como um patógeno emergente, capaz de colonizar a mucosa intestinal. Um número considerável de trabalhos realizados em diversos países vem mostrando que EPECa está significativamente associada aos casos diarréicos endêmicos (VIEIRA et al., 2001; DULGER et al., 2003; WANI et al., 2006) ou surtos diarréicos (YATSUNAGl et al., 2002; JENKINS et al., 2003). Em 2006, Nguyen e colaboradores descreveram dados de pacientes infectados por EPEC atípicas que desenvolveram diarréia moderada, não associada à desidratação, febre, vômito ou dor abdominal. No entanto, a duração do quadro diarréico era 
significantemente maior que as causadas por outros patógenos ou mesmo por EPEC típicas.

\subsection{Mecanismos de patogenicidade}

EPEC típicas são caracterizadas por induzirem uma alteração histopatológica no intestino conhecida como lesão A/E (attaching and effacing). A lesão ocorre por meio de um mecanismo de virulência complexo, que induz a degradação das microvilosidades e altera a morfologia normal da região apical dos enterócitos. O modelo de patogênese de EPEC se divide em três fases: aderência inicial, injeção de fatores e transdução de sinal e contato íntimo (VIDAL et al., 2007).

A aderência, processo fundamental à patogênese, depende de uma adesina fimbrial conhecida como bundle forming pilus (BFP). Ela promove adesão bacteriana às células enterocíticas e tem seus genes codificados em um plasmídio de virulência denominado EAF ( $E$. coli adherence factor). O mesmo plasmídio EAF carrega ainda um ativador transcricional denominado plasmid encoded regulator (Per), o qual codifica um complexo regulador dos genes de virulência em EPEC (TOBE et al., 1999). Uma vez a bactéria aderida, ela injeta na célula uma série de proteínas por meio do sistema de secreção tipo III (SSTT). A maior parte destas proteínas está codificada no cromossomo de EPEC, dentro de uma ilha de patogenicidade de $35 \mathrm{~kb}$ conhecida como Locus of enterocite effacement (LEE). A última etapa da infecção por EPEC se caracteriza pela união íntima entre a bactéria e a célula hospedeira pela ligação de Tir (Translocated intimin receptor) com intimina e a formação de pedestais de actina.

As EPECt são bastante homogêneas em suas propriedades de virulência, pois expressam basicamente os fatores codificados pela ilha de patogenicidade cromossomal (LEE) e pelo plasmídio EAF. Já as EPECa também produzem a lesão $A / E$, mas não são portadoras do plasmídio $E A F$ e 
até o momento não foi descrito nenhum fator de virulência exclusivo desse patotipo.

Nos diferentes patotipos de E. coli diarreiogênica tanto as toxinas, como as proteínas efetoras são mais diversos do que as estruturas da superfície bacteriana e estão envolvidas em diversos processos celulares como 0 aumento da concentração de mensageiros intracelulares, AMP cíclico, GMP cíclico e $\mathrm{Ca}^{2+}$ que levam à secreção anormal de íons, bem como a quebra do RNA ribossomal, interrompendo assim, a síntese de proteínas levando à intoxicação das células epiteliais e endoteliais (FASANO, 1990).

\subsection{Toxinas hemolíticas}

Toxinas hemolíticas são produzidas por muitas bactérias Gram positivas e Gram negativas (família Pasteurelaceae, B. pertussis, V. cholerae entre outros) representando um grupo de toxinas bacterianas, que ao contrário de outras toxinas, não são internalizadas pelas células alvo, mas agem ativamente sobre as membranas celulares, causando distúrbios na sua estrutura e função, manifestadas sob a forma de lise e conseqüentemente morte celular. Hemolisinas não são líticas apenas aos eritrócitos, mas causam também danos a fibroblastos, plaquetas, monócitos, granulócitos e células endoteliais e do miocárdio. Além disso, muitas dessas toxinas são reconhecidas por estarem envolvidas na patogênese bacteriana (JURGENS et al., 2002).

Essas citolisinas pertencem a um grupo de proteínas formadoras de poros (pore-forming protein), e representam a família das proteínas RTX. A designação RTX (repeats in toxin) é baseada na presença de várias cópias de uma repetição de nove aminoácidos (Leucina-X-Glicina-Glicina-X-Glicina(Asparagina/Aspartato)-Aspartato-X) na molécula. Esta família de toxinas é especialmente notável porque freqüentemente exibem diferentes especificidades entre a célula alvo e o hospedeiro. A atividade das toxinas desta família é dependente de cálcio, sendo que os íons $\mathrm{Ca}^{+2}$ se ligam ao 
domínio repetitivo da proteína estabilizando a formação de estruturas $\beta$ pregueadas necessárias à interação com a célula hospedeira. Formam também canais na membrana lipídica das células alvo o que pode levar à lise osmótica, apoptose ou subversão das funções celulares. Os genes especificamente envolvidos na síntese e secreção de uma toxina da família RTX são geralmente organizados em um único operon com quatro genes contíguos designados $r t x \mathrm{C}, r t x \mathrm{~A}, r t x \mathrm{~B}$, e $r t x \mathrm{D}$. (POPOFF; GENY, 2006).

A habilidade de certos isolados de $E$. coli em lisar eritrócitos de diferentes espécies de mamíferos (hemolisinas) foi detectada em cultura líquida de $E$. coli isolada de abscesso humano e de materiais fecais (KAYSER, 1903). Os primeiros trabalhos apresentando associação entre a produção de hemolisina e infecção do trato urinário (ITU) causada por E. coli em seres humanos, foram descritos na década de 20. Desde então, os estudos sobre hemolisinas vêm abordando principalmente suas propriedades biológicas e bioquímicas e sua significância enquanto fator de virulência em infecções causadas por $E$. coli (BEUTIN, 1991).

A caracterização genética, bioquímica e funcional da $\alpha$-hemolisina torna essa toxina a mais bem caracterizada dentre todas as hemolisinas de $E$. coli (WELCH, et al., 1990). A a-hemolisina apresenta aproximadamente $110 \mathrm{kDa}$ e sua subunidade hemolítica é codificada pelo gene hlyA sendo que a toxina ativa pode ser obtida diretamente do sobrenadante da cultura bacteriana filtrada. Sua expressão é observada em placas contendo ágar sangue (de carneiro); com lise celular, após 3 horas de incubação, característica da fase de crescimento exponencial.

A $\beta$-hemolisina é uma toxina bastante similar em sua atividade quando comparada à a-hemolisina, no entanto, não é secretada pela bactéria necessitando diferentes métodos de extração protéica para ser obtida. Um terceiro tipo de hemolisina denominada $y$-hemolisina foi descrita em mutantes resistentes ao ácido nalidíxico, mas até hoje não está bem caracterizada, no entanto, ambas toxinas necessitam de íon $\mathrm{Ca}^{+2}$ (BEUTIN et al., 1990). 
Em 1988, Beutin et al. descreveram um quarto tipo de hemolisina obtidos de crianças com gastrenterite, e que foi denominada enterohemolisina (EHly) justamente pelo fato de estar associada ao patotipo enterohemorrágico.

A EHly também conhecida como hemolisina de EHEC, é geneticamente e imunologicamente distinta de a-hemolisina. O padrão hemolítico da EHly difere das demais hemolisinas por apresentar zona de lise menor, aspecto turvo e com aparecimento tardio, já que a maior concentração da toxina é detectada no final da fase log do crescimento bacteriano. Essa toxina também é codificada pelo gene ehxA, seu tamanho estimado é de $35 \mathrm{kDa} e$ freqüentemente é liberada no meio extracelular (JURGENS et al., 2002; COOKSON et al., 2007). Acredita-se ainda que a EHly seja sintetizada como uma pró-toxina inativa, necessitando de acilação feita pela proteína EhxC e secreção mediada por EhxB e EhxD por meio de um sistema de translocação transmembrana específico (COOKSON et al., 2007).

Quanto ao seu mecanismo de ação, experimentos realizados com EHly clonada a partir do plasmídio p0157, mostram sua capacidade de formação de canais permeáveis a íons pela integração da toxina na bicamada lipídica, o que mostra que se trata de uma toxina da família RTX com alta atividade lítica (SCHIMIDT et al., 1996). Outro estudo, realizado por Figueiredo e colaboradores em 2003 mostrou que a enterohemolisina altera e promove o rompimento celular por um mecanismo semelhante ao de um detergente. Além disso, ela induz apoptose em células do epitélio intestinal como aerolisina, listeriolisina e alpha toxina de Stapylococcus aureus e esse dano celular pode estar envolvido no desenvolvimento do processo diarréico (FIGUEIREDO et al., 2007).

Acredita-se também que a função hemolítica pode não estar diretamente envolvida com a virulência em si, mas sim participar da sobrevivência e persistência da bactéria fora do ambiente gastrointestinal onde há grande necessidade de obtenção de ferro (BOCZEK et al., 2006). já que o locus ehx está comumente associado a $E$. coli isoladas do meio ambiente ou de origem 
animal (ovinos e bovinos) que não possuem fatores de virulência bem estabelecidos como stx e eae.

A literatura descreve ainda associação de ehx aos sorotipos de STEC 0157:H7, O26:H11, O103:H2, O111:H-, O113, H21, O5:H- e em EPEC atípica, em isolados obtidos de bovinos e ovinos pertencentes aos seguintes sorotipos: O26:H11, O69:H32, O76:H-, O84:H38, O115:H-, O123:H11, O123:H-, O145:H-, 0149:H-, O149:H7 e 0168:H8. Deste modo, a caracterização genotípica e fenotípica de EHly está sendo usada para buscar-se uma relação de proximidade filogenética entre STEC, EPECa e EPEC (COOKSON et al., 2007).

\subsection{Expressão toxigênica}

Existe um consenso de que o nível de expressão de toxinas é dependente do meio em que a bactéria é cultivada. Em 1983, O’Brien et al. descreveram três categorias de $E$. coli produtora da toxina de Shiga compreendendo: baixa, moderada e alta produção da toxina. Após esta descrição, diferentes meios de cultivo ou de enriquecimento foram empregados em diagnóstico de STEC com o objetivo de detectar melhores níveis de expressão de Stx. Essa assertiva pode ser confirmada tanto para Stx (ROCHA e PIAZZA, 2007) como para plasmid encoded toxin (pet) produzida por E. coli enteroagregativa (EAEC) (VILHENA-COSTA et al., 2006).

A variação na expressão de fatores de virulência bacterianos pode também ser influenciada pela presença ou ausência de determinados componentes nos meios de cultivo. A bile é uma secreção que participa ativamente dos processos digestivos humanos e inúmeros estudos mostram que bactérias, particularmente patógenos entéricos podem usar os sais biliares como sinal para regularem a expressão de fatores de adesão, invasão ou outros mecanismos de virulência (TORRES et al., 2007).

Com relação a toxinas hemolíticas uma variação na atividade toxigênica de cepas de STEC $\beta$-hemolíticas foi observada previamente por Chart et al. 
(1998). Recentemente, Cooksoon et al. (2007) descreveram diferentes fenótipos enterohemolíticos em função dos seis subtipos obtidos por PCR-RFLP do gene ehxA em isolados de STEC e EPECa.

\subsection{Adesão de proteínas bacterianas à matriz extra celular}

Proteínas de membrana externa, proteínas associadas à membrana celular de bactérias e proteínas secretadas (CHOY et al., 2007) de microrganismos como Staphylococcus aureus, Streptococcus pyogenes, Neisseria gonorrhoeae, Leptospira interrogans e Mycobacterium spp ligam-se a componentes de matriz extracelular e indiretamente se conectam a integrinas auxiliando a interação entre o microrganismo e a célula eucariótica (LIANG, JI 2006; BARBOSA et al.,2006).

Nos patógenos em que as hemolisinas são fundamentais na patogênese é avaliada comumente a adesão ou a interação da molécula toxigênica com componentes do tecido vascular e/ou elementos sanguíneos. A ligação da bactéria a um ou mais componentes teciduais como colágeno I e IV, laminina, fibronectinas celular e plasmática seriam indícios de que essas moléculas estariam sendo usadas como substrato de adesão e colonização do hospedeiro pela bactéria patogênica (LOWRANCE et al., 1988). Um exemplo prático é a pielonefrite, seguida de septicemia causadas por infecção por $E$. coli uropatogênicas (UPEC). Esse patotipo tem como um de seus principais fatores de virulência a $\alpha$-hemolisina. Essa toxina, mesmo em baixas concentrações, provoca danos à barreira celular endotelial, aumentando a permeabilidade do tecido microvascular favorecendo a invasão bacteriana a outros tecidos do hospedeiro (SUTTORP et al., 1990). 


\section{MATERIAL E MÉTODOS}

\subsection{Isolados bacterianos e preparo de sobrenadantes}

Os noventas isolados utilizados nesse trabalho foram definidos anteriormente como EPECa por PCR pela presença do gene eae e ausência do plasmídio EAF, isolados em um estudo epidemiológico realizado em Salvador (BA) durante os meses de fevereiro de 2002 e setembro de 2003 (BUERIS et al., 2007).

Os isolados C3888 (O26:H-) (BEUTIN et al., 1989) e 268 (O48:H6) foram utilizados como controles de amostras produtoras e não produtoras de enterohemolisina, respectivamente. O isolado U4-41 foi utilizado como controle positivo na produção de $\alpha$-hemólisina (WELCH et al., 1983).

\subsection{Condições de cultivo bacteriano}

\subsubsection{Meios líquidos}

Os isolados bacterianos foram cultivados em tubos contendo $3 \mathrm{~mL}$ dos diferentes meios de cultivo (Tabela 1) incubados sob agitação constante de 150 rpm por $18 \mathrm{~h}$ a $37^{\circ} \mathrm{C}$. Essas condições são válidas para todas as situações de cultivo, exceto quando mencionado. 
Tabela 1. Composição dos principais meios de cultivo utilizados.

\begin{tabular}{cccc}
\hline & Evans & Meio Mínimo & TSB \\
\hline $\begin{array}{c}\text { Extrato de } \\
\text { levedura }\end{array}$ & $0,15 \%$ & - & - \\
Caseína & - & $15 \%$ & $1,7 \%$ \\
$\mathrm{Na}_{2} \mathrm{HPO}_{4} \cdot 2 \mathrm{H}_{2} \mathrm{O}$ & - & $6,4 \%$ & - \\
$\mathrm{NaCl}$ & $0,25 \%$ & $0,25 \%$ & $0,5 \%$ \\
$\mathrm{KH}_{2} \mathrm{PO}_{4}$ & $0,871 \%$ & - & - \\
$\mathrm{MnCl}_{2} \cdot 4 \mathrm{H}_{2} \mathrm{O}$ & $0,0005 \%$ & - & - \\
$\mathrm{MgSO}_{4}$ & $0,005 \%$ & - & - \\
$\mathrm{FeCl}_{3} \cdot 6 \mathrm{H}_{2} \mathrm{O}$ & $0,0005 \%$ & - & - \\
$\mathrm{K}_{2} \mathrm{HPO}_{4}$ & - & - & $0,25 \%$ \\
$\mathrm{Peptona}$ & - & - & $0,3 \%$ \\
$\mathrm{NH}_{4} \mathrm{Cl}$ & - & $0,5 \%$ & - \\
Lactose & - & $2 \%$ & - \\
$\mathrm{Glicose}$ & - & - & $0,25 \%$ \\
\hline
\end{tabular}

\subsubsection{Meio sólido}

As placas de ágar sangue foram preparadas adicionando-se a um meio base (ágar tripticaseína de soja) esterilizado por autoclavação, hemácias de carneiros (Newprov) lavadas, na concentração final de $5 \%$ ou hemácias humanas coletadas com heparina $5 \mathrm{U} / \mathrm{mL}$ e solução esterilizada de $\mathrm{CaCl}_{2}$ na concentração final de 10 mM (BEUTIN, 1991).

Para lavagem das hemácias, um volume apropriado de sangue desfibrinado de carneiro foi submetido à centrifugação a $2.500 \mathrm{~g}$ por $10 \mathrm{~min}$ e o sobrenadante desprezado. As hemácias foram ressuspensas em um volume de solução salina tamponada com fosfato $\mathrm{pH}$ 7,2 (PBS) equivalente ao volume inicial de sangue. Após duas lavagens adicionais, os eritrócitos foram 
ressuspensos em PBS e acrescidos ao meio base resfriado a uma temperatura de $40-45^{\circ} \mathrm{C}$.

\subsection{Pesquisa de hemolisinas em isolados de EPEC atípicas}

\subsubsection{Reação de polimerase em cadeia (PCR)}

A presença do gene ehxA foi pesquisada através de reações em cadeia da polimerase (PCR). Os pares de iniciadores e os ciclos de amplificação utilizados, assim como os tamanhos dos fragmentos amplificados em cada reação, encontram-se descritos na tabela 2. Para visualização dos resultados os fragmentos amplificados foram submetidos a eletroforese em gel de agarose $1 \%$ e corados em solução de brometo de etídio $0,5 \mu \mathrm{g} / \mathrm{mL}$, fotografado em transiluminador com luz ultra violeta.

Tabela 2. Iniciadores.

\begin{tabular}{|c|c|c|c|c|c|}
\hline Gene & Primer & Seqüência (5’ - 3') & $\begin{array}{c}\text { Temperatura }\left({ }^{\circ} \mathrm{C}\right) \\
\text { de anelamento }\end{array}$ & $\begin{array}{l}\text { Tamanho }(\mathrm{pb}) \\
\text { do fragmento }\end{array}$ & Referência \\
\hline \multirow[t]{4}{*}{ ehxA } & eha 1 & GGTGCAGCAGAAAAAGTT & 55 & 1501 & Beutin et \\
\hline & & GTAG & & & al., 2004 \\
\hline & eha 4 & TCTCGCCTGATAGTATTT & & & \\
\hline & & GGTA & & & \\
\hline
\end{tabular}

\subsubsection{Ensaio de hemólise em ágar}

Volumes de $2 \mu \mathrm{L}$ do cultivo bacteriano nos diferentes meios propostos ou do isolado em suas condições de estocagem a $-80{ }^{\circ} \mathrm{C}$ (caldo LB suplementado com glicerol V/V), foram aplicados nas placas de ágar sangue (item 4.2.2) e incubados a $37^{\circ} \mathrm{C}$ juntamente com os isolados controles. Os resultados dos testes de hemólise foram determinados visualmente pela observação da formação de halos de hemólise ao redor da colônia bacteriana, após 3h e $24 \mathrm{~h}$ de incubação a $37^{\circ} \mathrm{C}$ (BEUTIN et al., 1989). 


\subsubsection{Ensaio de hemólise em meio líquido}

Os ensaios de hemólise líquida foram padronizados como preconizados por Bhakdi et al. (1986) em que hemácias de carneiros (Newprov) lavadas (item 4.2.2) foram sedimentadas por centrifugação a $3.000 \mathrm{~g}$ por 5 min e a papa de hemácias formada foi considerada uma suspensão a 100\%. Para determinação da curva de lise eritrocítica e definição da melhor concentração de células para o ensaio, placas de 96 poços de poliestireno de fundo U (Polysorp, NUNC) receberam $100 \mu \mathrm{L}$ de suspensão de hemácias em PBS pH 7,2 (triplicatas) nas concentrações de 0,5\%,1\%,1,5\% e 2\%. Como controle positivo de hemólise utilizou-se $100 \mu \mathrm{L}$ de água destilada estéril. A placa foi então incubada em câmara úmida por $2 \mathrm{~h}$ a $37^{\circ} \mathrm{C}$ seguido de centrifugação a $12.000 \mathrm{~g}$ por $1 \mathrm{~min}$. O sobrenadante obtido foi transferido para uma nova placa em que foi feita a leitura em filtro de $540 \mathrm{~nm}$ (Reader Multiskan - Labsystems, EUA). O valor da absorbância deve ser menor que 1,0 DO e uma unidade de hemólise equivale a $50 \%$ do valor obtido nesse ensaio.

Os isolados bacterianos foram cultivados e ensaiados sob condições prédeterminadas (item 4.2.1). Coletou-se $100 \mu \mathrm{L}$ de pré-inóculo semeados novamente em $3 \mathrm{~mL}$ do mesmo meio de cultivo sob agitação de $150 \mathrm{rpm}$ a $37^{\circ} \mathrm{C}$ até que atingissem densidade ótica entre 0,6 e 0,8 com leitura feita em filtro de $600 \mathrm{~nm}$.

Em placas de 96 poços de poliestireno de fundo $U$ adicionou-se $V / V$ da suspensão de hemácias na concentração ideal com o cultivo bacteriano que foram incubados em câmara úmida por $2 \mathrm{~h}$ a $37^{\circ} \mathrm{C}$ e passado esse período centrifugados a $12.000 \mathrm{~g}$ por $1 \mathrm{~min}$. O sobrenadante obtido foi transferido para uma nova placa em que foi feita a leitura em filtro de $540 \mathrm{~nm}$ (Reader Multiskan - Labsystems, EUA). Os resultados de porcentagem de lise de hemácias são dados pela razão:

A $540 \mathrm{~nm}$ toxina

A $540 \mathrm{~nm}$ água 


\subsection{Obtenção de Anticorpo Policlonal}

\subsubsection{Preparo de antígeno}

O antígeno para imunização foi obtido a partir de $25 \mathrm{~mL}$ de sobrenadante de cultivo da cepa padrão (C3888, O26:H-) (BEUTIN et al., 1989) produtora de enterohemolisina. Após o cultivo em TSB, o isolado bacteriano foi centrifugado a $10.000 \mathrm{~g}$ por $15 \mathrm{~min}$ e o sobrenadante liofilizado e ressuspenso em $1 \mathrm{~mL}$ de água destilada. A concentração protéica foi determinada pelo método de Bradford (BRADFORD, 1976).

\subsubsection{Imunização}

Ratos Wistar de 40-50 dias de idade foram imunizados intraperitonealmente com $100 \mu \mathrm{g}$ do antígeno emulsificado V/V com adjuvante Montanide (SEPPIC- França) e três doses de reforços do antígeno na mesma concentração protéica diluídos em solução salina tamponada $0.01 \mathrm{M} \mathrm{pH} 7.2$ (PBS), nos $21^{\circ}, 31^{\circ}$ e $41^{\circ}$ dias após a primeira imunização.

Após sete dias da última dose de reforço foi feita uma sangria de prova para verificação dos títulos de anticorpos específicos no soro por ELISA (ENGVALL; PERLMANN, 1971); a sangria total dos animais foi realizada por punção cardíaca e o soro obtido armazenado a $-20 \stackrel{\circ}{ }$ C. Antes da imunização foi realizada uma sangria para obtenção de soro pré-imune. 


\subsubsection{Adsorção ${ }^{1}$ dos soros imunes}

O soro obtido foi adsorvido com o isolado bacteriano não produtor de enterohemolisina 268 (O48:H6), crescido nas mesmas condições descritas no item 4.2.1 e centrifugado a $10.000 \mathrm{~g}$ por $15 \mathrm{~min}$. O sedimento obtido foi ressuspenso em PBS pH 7,2 contendo $1 \mathrm{mM}$ de fluoreto de fenilmetilsulfonil (PMSF), centrifugado novamente a $10.000 \mathrm{~g}$ por $15 \mathrm{~min}$. Os sedimentos obtidos foram mantidos $\mathrm{a}-20{ }^{\circ} \mathrm{C}$ até o momento do uso. Para adsorção, cerca de $1,5 \mathrm{~mL}$ de soro foram homogeneizados com o sedimento armazenados nos tubos tipo eppendorf e mantidos sob agitação por $2 \mathrm{~h}$ à temperatura ambiente, incubados por $16-18 \mathrm{~h}$ a $4{ }^{\circ} \mathrm{C}$. Após incubação, a mistura de soro e bactéria foi centrifugada $5.000 \mathrm{~g}$ por $10 \mathrm{~min}$ e o precipitado descartado, sendo esse procedimento repetido duas vezes. Após a última adsorção, os soros foram filtrados em membrana de $0,22 \mu \mathrm{m}$ e mantidos a $-20{ }^{\circ} \mathrm{C}$ até o momento do uso.

\subsection{ELISA}

\subsubsection{Preparo de antígeno}

\section{-Bactérias fixadas:}

Quando foram utilizadas células bacterianas fixadas, procedeu-se 0 cultivo dos isolados conforme anteriormente descrito na seção 4.2.1, sendo o cultivo centrifugado a $10.000 \mathrm{~g}$ por $15 \mathrm{~min}$, o sobrenadante descartado e adicionado $1 \mathrm{~mL}$ de tampão carbonato/bicarbonato 0,05 M pH 9,6 para ressuspender o precipitado. Tal lavagem foi repetida por duas vezes consecutivas, o precipitado foi ressuspenso e diluído até atingir uma DO (Abs $600 \mathrm{~nm}$ ) de 0,5 e um volume de $100 \mu \mathrm{L}$ foi adicionado à placa, que foi centrifugada a $5.000 \mathrm{~g}$ por $5 \mathrm{~min}$. O sobrenadante foi então descartado e adicionou-se $100 \mu \mathrm{L}$ de solução de $0,5 \%$ de $\rho$-formaldeído em solução tampão de carbonato/bicarbonato $0,05 \mathrm{M} \mathrm{pH} \mathrm{9,6.}$

1. Adsorção: s.f. Incorporação de uma substância à superfície de outra 


\section{-Sobrenadante :}

Para sensibilização da placa de ELISA com a fração do sobrenadante procedeu-se o cultivo dos isolados conforme anteriormente descrito na seção 4.2.1, sendo o cultivo centrifugado a $10.000 \mathrm{~g}$ por $15 \mathrm{~min}$ e $100 \mu \mathrm{L}$ do sobrenadante foi coletado e aplicado diretamente nos poços.

\section{-Células bacterianas rompidas:}

O precipitado resultante do processo acima descrito foi ressuspenso em $1 \mathrm{~mL}$ de PBS pH 7,2 e lavado por centrifugação a $10.000 \mathrm{~g}$ por $15 \mathrm{~min}$ por duas vezes. Em seguida foi incubado com $500 \mu \mathrm{L}$ de solução de polimixina (1 $\mathrm{mg} / \mathrm{mL}$ em PBS pH 7,2) a $37{ }^{\circ} \mathrm{C}$ por $30 \mathrm{~min}$, centrifugado a $10.000 \mathrm{~g}$ por $15 \mathrm{~min}$. Um volume de $100 \mu \mathrm{L}$ do sobrenadante foi adicionado aos poços.

\subsubsection{Padronização}

Para os testes de ELISA, placas de fundo chato (Maxi Sorp - NUNC) foram sensibilizadas com $100 \mu \mathrm{L}$ de suspensão de precipitado rompido, ou 100 $\mu \mathrm{L}$ de sobrenadante de cultivo dos isolados recém cultivados ou com as próprias bactérias fixadas (item 4.5.1). As placas sensibilizadas foram incubadas a $4{ }^{\circ} \mathrm{C}$ em câmara úmida por 16-18h. Após bloqueio com a solução de leite desnatado 5\% em PBS pH 7,2 e sucessivas lavagens com solução de PBS Tween $0,05 \%$ (PBS-T), as placas foram incubadas com o soro imune em diluições seriadas de 1:100 a 1:10.000, e posteriormente, incubadas com soro de cabra anti-rato conjugado à peroxidase, diluído 1:10.000. As reações foram reveladas com $0,5 \mu \mathrm{g} / \mathrm{mL}$ de $\sigma$-fenilenodiamino (OPD), peróxido de hidrogênio $\left(\mathrm{H}_{2} \mathrm{O}_{2}\right)$ e a leitura realizada a $492 \mathrm{~nm}$ em espectrofotômetro (ELISA reader Multiskan, Labsystems). 


\subsubsection{Ensaios de ELISA para diferenciação de amostras produtoras e não produtoras de EHly}

Os isolados controles (C3888 e 268) foram cultivados somente em meio TSB como descritos no item 4.2.1. Posteriormente foram centrifugados a 10.000 g por $15 \mathrm{~min}$ e seus sobrenadantes foram coletados. Alíquotas de $100 \mu \mathrm{L}$ dos sobrenadantes sensibilizaram as placas de fundo chato (Maxi Sorp - NUNC) a $4 \stackrel{\circ}{ } \mathrm{C}$ em câmara úmida por 16-18h. Após bloqueio com solução de leite desnatado $5 \%$ e sucessivas lavagens com PBS-T, as placas foram incubadas com o soro policlonal anti-enterohemolisina na diluição de 1: 200 por $1 \mathrm{~h}$. Posteriormente, foram incubadas com o soro de cabra anti-rato conjugado à peroxidase, diluído 1:10.000. As reações foram reveladas com OPD na presença de $\mathrm{H}_{2} \mathrm{O}_{2}$ e a leitura foi realizada a $492 \mathrm{~nm}$ em espectrofotômetro. Para determinação da DO de corte desse ensaio (cut off) testou-se 30 isolados sabidamente não hemolíticos por testes de hemólise em placa ou pela ausência do gene ehxA por PCR. Esse experimento foi realizado em triplicatas e o resultado demonstrado refere-se a dois ensaios independentes. A média das densidades óticas obtidas foi multiplicada por 4 DO definindo assim o valor de 0,09 como separação entre os isolados produtores ou não de EHly.

\subsection{SDS/PAGE e Immunoblotting}

Os sobrenadantes dos isolados bacterianos cultivados sob as mesmas condições descritas no item 4.2.1 foram submetidos à eletroforese em gel de poliacrilamida na presença de SDS a 12\% (SDS/PAGE) em condições desnaturantes (LAEMMLI, 1970; STUDIER, 1973). Cinqüenta microgramas dos componentes protéicos do sobrenadante foram misturados em 1/4 do volume de tampão de dissociação $(0,5 \mathrm{M}$ Tris- $\mathrm{HCl}, \mathrm{pH} 6,8,2 \%$ dodecil sulfato 
de sódio - SDS, $10 \%$ glicerol e 0,1\% azul de bromofenol) e aquecidas à temperatura de $100 \stackrel{\circ}{\circ}$ por 5 min.

As proteínas separadas por SDS/PAGE foram transferidas eletroforeticamente para a membrana de nitrocelulose (Hybond-C Extra Amersham) (TOWBIN et al., 1979). Após bloqueio, as membranas foram incubadas por 16-18h com soro de rato não adsorvido ou adsorvido duas vezes, diluído 1:1.000, seguido da incubação com soro de cabra anti-rato conjugado à peroxidase 1:10.000 (Zymed). As membranas foram reveladas com 0,19 $\mathrm{mg} / \mathrm{mL}$ de diaminobenzidina (DAB) em presença de $\mathrm{H}_{2} \mathrm{O}_{2}$ (Sigma Chemical Co.). Foi utilizado como padrão de massa molecular as proteínas de 97 a 14,4 kDa (LMW - Amersham Biosciences).

\subsection{Ensaio de adesão das proteínas secretadas a componentes de matriz extracelular}

Na padronização dos ensaios de adesão das proteínas secretadas aos componentes de matriz extracelular foram utilizados os isolados controles (C3888 e 268). Os antígenos foram obtidos a partir de $25 \mathrm{~mL}$ de sobrenadante de cultivo conforme descrito no item 4.2.1. Após centrifugação a $10.000 \mathrm{~g}$ por $15 \mathrm{~min}$, o sobrenadante foi liofilizado e ressuspenso em $1 \mathrm{~mL}$ de água destilada, e a concentração protéica foi determinada pelo método de Bradford (BRADFORD, 1976).

Diluições de proteína total entre $1 \mu \mathrm{g}$ e $50 \mu \mathrm{g}$ foram ensaiadas e definiuse $20 \mu \mathrm{g}$ como concentração ideal de proteína. O soro imune foi utilizado na diluição 1:1.000 e o soro de cabra anti-rato conjugado à peroxidase diluído 1:10.000. Nessas condições os isolados de EPECa enterohemolíticos e nove não hemolíticos foram preparados como os controles e testados por ELISA onde placas de fundo chato (Maxi Sorp - NUNC) foram sensibilizadas com $1 \mu \mathrm{g}$ dos componentes de matriz extracelular (laminina, colágeno Tipo I, colágeno Tipo IV, fibronectina celular, fibronectina plasmática, fibronectina plasmática 
fragmento $30 \mathrm{kDa}$-domínio de interação com heparina, fibronectina plasmática fragmento $45 \mathrm{kDa}$ - domínio de interação com gelatina e BSA - Bovine Serum Albumin, controle negativo), diluídos em $100 \mu \mathrm{L}$ de PBS. Todos os componentes foram adquiridos comercialmente (Sigma). As placas foram mantidas a $37 \stackrel{\circ}{\circ}$ por $2 \mathrm{~h}$ e posteriormente lavadas três vezes com PBS-T $0,05 \%$. O bloqueio foi feito com $200 \mu \mathrm{L}$ de BSA $1 \%$ por 1 h a $37 \stackrel{\circ}{\circ} \mathrm{C}$, seguido de incubação a $4 \stackrel{\circ}{\circ}$ por $16 \mathrm{~h}$. Vinte microgramas de proteína (sobrenadante concentrado) de todos os isolados submetidos a este ensaio foram diluídos em PBS e adicionados a cada poço. Após um período de incubação de $1 \mathrm{~h}$ e $30 \mathrm{~min}$ a $37 \stackrel{\circ}{\circ}$, os poços foram lavados seis vezes com PBS-T 0,05\%. As proteínas aderidas foram detectadas pela adição de anti-soro produzido em rato seguida de uma incubação por $1 \mathrm{~h}$ com soro de cabra anti-rato conjugado à peroxidase. Após três lavagens com PBS-T 0,05\%, foi adicionado OPD (0,04\%) diluído em tampão citrato-fosfato $\left(\mathrm{pH} \mathrm{5,0)} \mathrm{e} \mathrm{0,01 \%} \mathrm{de} \mathrm{H}_{2} \mathrm{O}_{2}\right.$. Após 20 min, a reação foi interrompida pela adição de $50 \mu \mathrm{l}$ de $\mathrm{H}_{2} \mathrm{SO}_{4} 8 \mathrm{~N}$. A absorbância a $492 \mathrm{~nm}$ foi determinada em leitor de microplacas.

\subsection{Análise estatística}

As densidades óticas obtidas pelos ensaios de ELISA foram analisadas pela média e erro padrão da média utilizando GraphPad Prism 3.0 ${ }^{\circledR}$. As correlações entre os dados foram feitas utilizando o teste $t$ de Student. Os isolados bacterianos foram considerados produtores ou não de enterohemolisina quando a variância foi significantemente diferente. 


\section{RESULTADOS}

\subsection{Identificação dos isolados enterohemolíticos}

Inicialmente, avaliou-se a atividade hemolítica nos isolados de EPECa aplicando-se $2 \mu \mathrm{L}$ do cultivo bacteriano diretamente de seus estoques a $-80^{\circ} \mathrm{C}$ nas placas de ágar sangue. No conjunto total dos 90 isolados de EPECa detectou-se a prevalência de $2,7 \%$ (3) e $5,4 \%$ (6) de a-hemólise e enterohemólise, respectivamente. Também se pesquisou a existência de diferença na atividade hemolítica dos isolados de EPECa quando cultivados em ágar sangue contendo hemácias de carneiro ou humanas. Os resultados apresentados na tabela 3 mostram que a presença de hemácias de carneiro no meio de cultivo proporciona maior sensibilidade na detecção de enterohemolisina quando comparada ao meio contendo hemácias humanas.

Tabela 3. Perfil hemolítico dos isolados de EPECa.

\begin{tabular}{cccc}
\hline $\begin{array}{c}\text { Isolado } \\
\text { bacteriano }\end{array}$ & Sorotipo & $\begin{array}{c}\text { Agar sangue de } \\
\text { carneiro }\end{array}$ & $\begin{array}{c}\text { Agar sangue } \\
\text { humano }\end{array}$ \\
\hline $\mathbf{1 2 2 4}$ & O25:H1 & $+($ EHly $)$ & $+($ EHly $)$ \\
$\mathbf{1 8 8 7}$ & O111:H38 & $+(\alpha)$ & $+(\alpha)$ \\
$\mathbf{2 1 0 3}$ & O26:H11 & $+(E H l y)$ & $+(E H l y)$ \\
$\mathbf{2 1 1 7}$ & ONT:H5 & $+(E H l y)$ & $+(E H l y)$ \\
$\mathbf{2 4 5 9}$ & O26:H11 & $+(E H l y)$ & $+(E H l y)$ \\
$\mathbf{2 7 7 5}$ & O113:H19 & $+(E H l y)$ & - \\
$\mathbf{2 9 2 3}$ & O34:H6 & $+(\alpha)$ & $+(\alpha)$ \\
$\mathbf{2 9 9 1}$ & O34:H- & $+(\alpha)$ & $+(\alpha)$ \\
$\mathbf{3 1 6 0}$ & O110: H- & $+(E H l y)$ & - \\
\hline
\end{tabular}




\subsection{Detecção do gene ehxA por Reação de Polimerização em Cadeia (PCR)}

$\mathrm{Na}$ identificação do gene ehxA nos isolados que demonstraram hemólise no ensaio padrão em ágar sangue de carneiro foi feita reação de PCR como descrito por Beutin et al., 2004. Dos seis isolados analisados somente os isolados 2103 e 2459 ambos O26:H11 amplificaram o gene, mostrando um fragmento de $1551 \mathrm{pb}$ (figura 1).

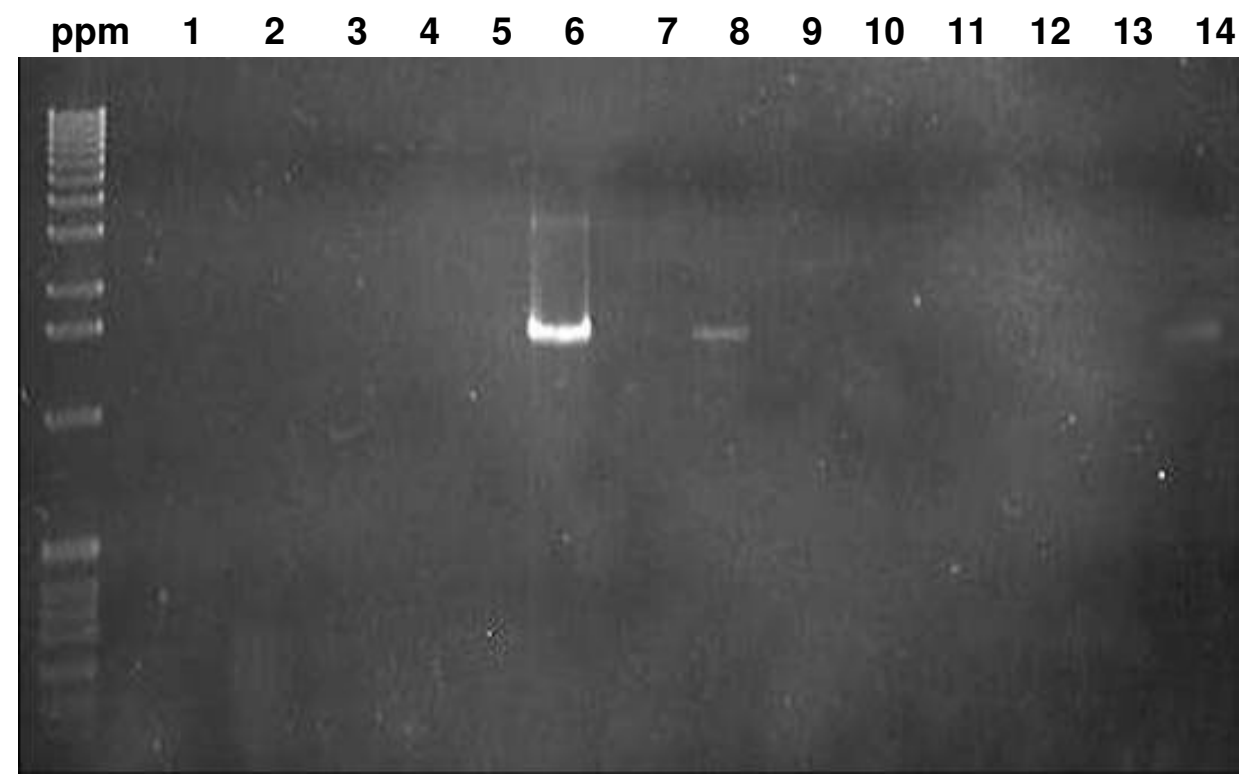

Figura 1. Eletroforese em gel de agarose $1 \%$ dos produtos de PCR para o gene ehxA dos isolados 1. 714, 2.1224, 3. 1887, 4. 2923, 5. 2991, 6. 2103, 7. 2117, 8. 2459, 9. 2775, 10. 3160, 11. 2062, 12. 4192, 13. água e 14. C3888. O gel foi corado em solução de $0,5 \mu \mathrm{g} / \mathrm{mL}$ de brometo de etídio e visualizado em luz UV. 


\subsection{Influência dos meios de cultivo na atividade hemolítica dos isolados}

Diferentes fatores de virulência têm expressões distintas de acordo com as condições de cultivo bacteriano. Com o objetivo de avaliar-se a interferência destes na expressão de hemolisina, os isolados foram pré-cultivados em meio Mínimo, Evans ou TSB e pelo ensaio de hemólise em placas de ágar sangue de carneiro detectou-se visualmente atividade hemolítica em $3 \mathrm{~h}$ para as produtoras de $\alpha$-hemolisina e 24h para as enterohemolíticas. Nos isolados 300, 2062 e 4192 ocorreu uma variação principalmente quando os isolados foram précultivados em meio Mínimo (Tabela 4 e Figura 2). Os demais isolados apresentaram o mesmo padrão hemolítico independente do meio em que foram pré-cultivados (Figura 2).

Tabela 4: Perfil hemolítico dos isolados em diferentes condições de pré-cultivo.

\begin{tabular}{ccccc}
\hline $\begin{array}{c}\text { Isolado } \\
\text { bacteriano }\end{array}$ & Estoque & MM & TSB & Evans \\
\hline 1224 & + & + & + & + \\
2117 & + & + & + & + \\
3160 & + & + & + & + \\
2103 & + & + & + & + \\
2459 & + & + & + & + \\
2775 & + & + & - & + \\
2062 & - & + & - & - \\
4192 & - & - & - & - \\
300 & - & - & - & - \\
2034 & - & - & - & - \\
4013 & - & + & - & - \\
268 & - & + & + & - \\
C3888 & + & + & + & + \\
1887 & + & + & + & + \\
2923 & + & + & + & + \\
2991 & + & + & + \\
U4-41 & + & + & + \\
\hline
\end{tabular}




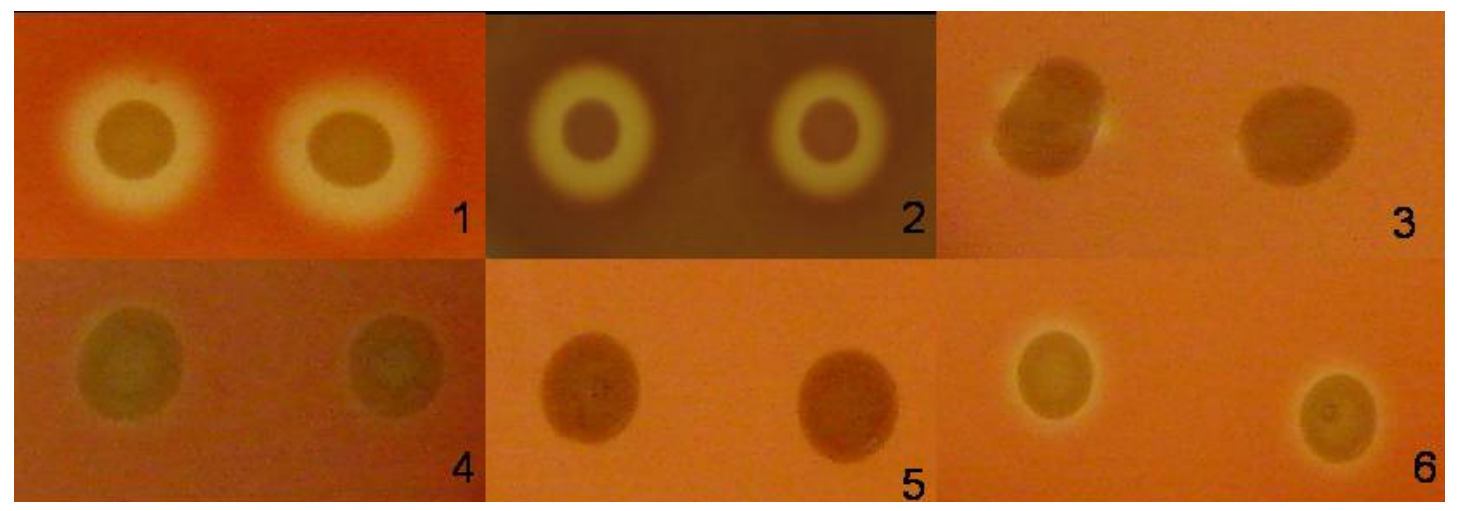

Figura 2. Figura representativa do ensaio hemolítico realizado em placas de ágar sangue de carneiro quando pré culltivados em meio Mínimo: 1. 2459 (O26:H11); 2. 1887 (O111:H38), 3. 2062 (O171:H48), 4. 4192 (O11:H25), 5. 268 (O49:H6), 6. C3888 (O26:H--).

\subsection{Avaliação da interferência de componentes dos meios de cultivo na expressão toxigênica avaliada por hemólise em placa de ágar sangue de carneiro}

O meio mínimo mostrou uma expressão diferenciada da toxina, comparando sua composição com os outros meios estudados, a lactose como fonte de carboidrato e caseína como fonte protéica sugeriam interferir na expressão toxigênica. Sendo assim, testou-se a lactose alterando a composição e a concentração de carboidrato dos meios TSB, Evans e meio mínimo. Além disso, avaliou-se também o MM contendo diferentes concentrações de caseína.

Como mostrado na figura 3 e tabela 5, o isolado 2062 e 4192 apresentaram perfil hemolítico quando pré-cultivado em TSB e MM contendo $0,25 \%$ de lactose. O isolado 4192 mostrou atividade hemolítica quando précultivado em TSB contendo $0,25 \%$ de lactose, como já mencionado anteriormente também apresentaram atividade hemolítica em sua composição original (meio Mínimo com $2 \%$ de lactose). 
Já o isolado $300(\mathrm{O} 1: \mathrm{H} 10)$ mostrou-se capaz de promover lise eritrocítica quando pré-cultivado em meio Mínimo em qualquer concentração de carboidrato e em meio Evans apenas não expressa efeito hemolítico na concentração de lactose de 2\%. Os isolados de números 2034 (ONT:H10) e 4013 (O88: $\mathrm{H}-)$ apresentaram também padrão variável na lise de eritrócitos, mas em particular um padrão pontual de hemólise então denominado HP (hemólise pontual) mostrado na figura 3. 


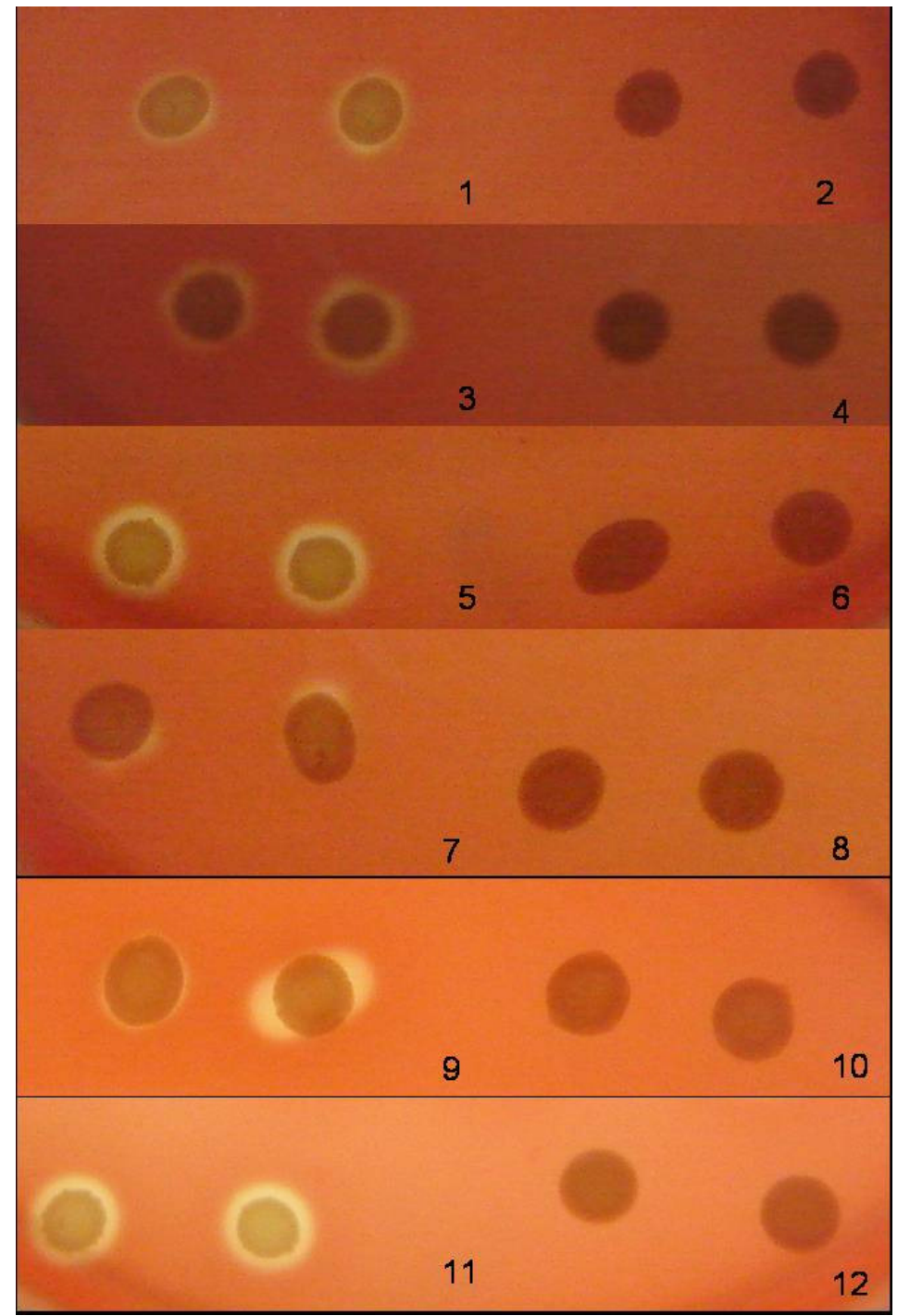

Figura 3. Figura comparativa do ensaio hemolítico realizado em placas de ágar sangue dos isolados quando expressaram perfil hemolítico e não hemolítico: 1 e 2. 2062, 3 e 4. 4192; 5 e 6. 300, 7 e 8. 2034; 9 e 10. 4013, 11. C3888 e 12. 268. 
Tabela 5: Perfil hemolítico dos isolados de EPECa em meios modificados

\begin{tabular}{|c|c|c|c|c|c|c|c|c|c|c|c|c|c|}
\hline & 1224 & 2117 & 3160 & 2103 & 2459 & 2775 & 2062 & 4192 & 300 & 2034 & 4013 & 268 & C3888 \\
\hline TSB $0,25 \%$ & + & + & + & + & + & + & + & + & - & $\mathrm{HP}$ & $\mathrm{HP}$ & - & + \\
\hline TSB 0,5\% & + & + & + & + & + & + & - & - & - & + & - & - & + \\
\hline TSB $1 \%$ & + & + & + & + & + & + & - & - & - & HP & - & - & + \\
\hline TSB 2\% & + & + & + & + & + & + & - & - & - & + & - & - & + \\
\hline MM 0,25\% & + & + & + & + & + & + & + & - & + & - & - & - & + \\
\hline MM $0,5 \%$ & + & + & + & + & + & + & - & - & + & $\mathrm{HP}$ & - & - & + \\
\hline MM 1\% & + & + & + & + & + & + & - & - & + & HP & - & - & + \\
\hline MM 2\% & + & + & + & + & + & + & + & + & + & - & - & - & + \\
\hline Evans $0,25 \%$ & + & + & + & + & + & + & - & - & + & - & - & - & + \\
\hline Evans $0,5 \%$ & + & + & + & + & + & + & - & - & + & - & + & - & + \\
\hline Evans 1\% & + & + & + & + & + & + & - & - & + & - & - & - & + \\
\hline Evans 2\% & + & + & + & + & + & + & - & - & - & - & - & - & + \\
\hline
\end{tabular}

$\mathrm{HP}=$ hemólise pontual 
Já a caseína foi utilizada nas concentrações de 0,15\%, 1,5\% e 15\%. Observou-se que quanto menor a concentração de caseína no meio de cultivo maior a atividade hemolítica, destacando o aumento notório na intensidade do halo hemolítico produzido pelo isolado número $3160(\mathrm{O} 110: \mathrm{H}-)$, indicados na tabela 6 por duas cruzes (++) e ilustrado na figura 4.

Tabela 6: Perfil hemolítico dos isolados de EPECa em meio mínimo modificado.

\begin{tabular}{cccc}
\hline $\begin{array}{c}\text { Isolado } \\
\text { bacteriano }\end{array}$ & MM 0,15\% & $\begin{array}{c}\text { Condições } \\
\text { MM 1,5\% }\end{array}$ & MM 15\% \\
\hline 1224 & + & + & + \\
2117 & + & + & + \\
3160 & ++ & ++ & + \\
2103 & + & + & + \\
2459 & + & + & + \\
2775 & + & - & + \\
2062 & - & - & + \\
4192 & - & + & + \\
300 & + & - & - \\
2034 & + & - & - \\
4013 & - & - & - \\
268 & - & + & + \\
C3888 & + & &
\end{tabular}
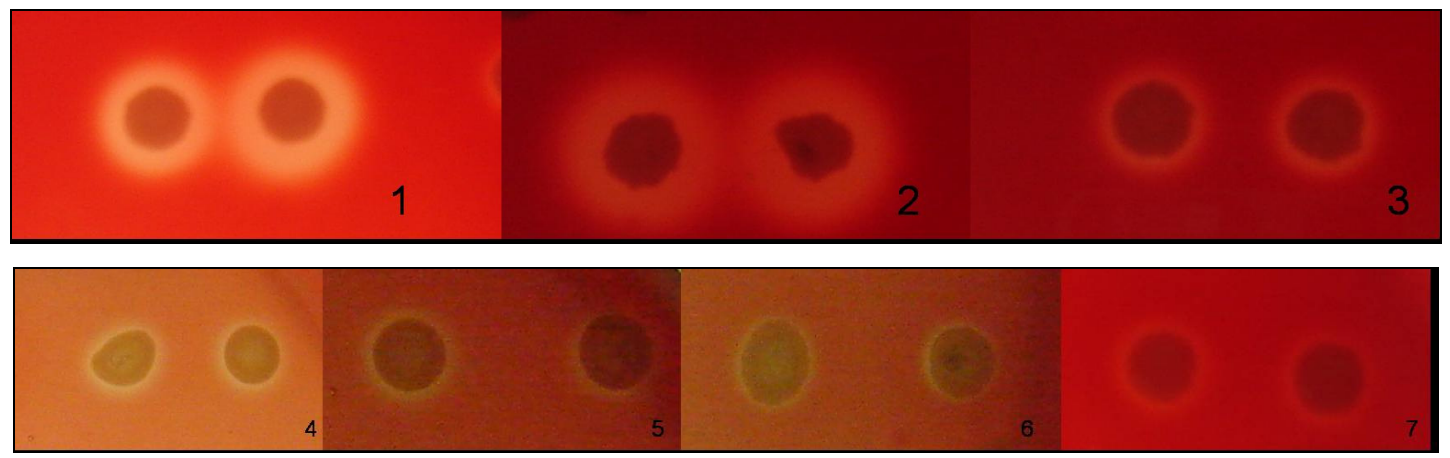

Figura 4. Perfil hemolítico do isolado 3160 cultivado em meio Mínimo: 1. 0,15\%, 2. $1,5 \%$ e 3. $15 \%$ de caseína. Perfil hemolítico dos isolados: 4.4192 (MM 15\%), 5. 300 (MM 0,15\%), 6. 300 (MM 1,5\%), 7. 2034 (MM $0,15 \%)$. 


\subsection{Método quantitativo da expressão de enterohemolisina}

\subsubsection{Padronização dos ensaios de hemólise líquida}

Como se observou uma expressão visualmente diferente da toxina entre os isolados em função da condição de pré-cultivo buscou-se um método capaz de quantificar a hemólise gerada. Deste modo, foi escolhido o ensaio de hemólise em meio líquido, utilizando hemácias em suspensão e medindo a liberação de hemoglobina por leitura de absorbância. Por este ensaio, definiuse $1 \%$ como a concentração ótima de hemácias para quantificação de hemoglobina livre (Figura 5).

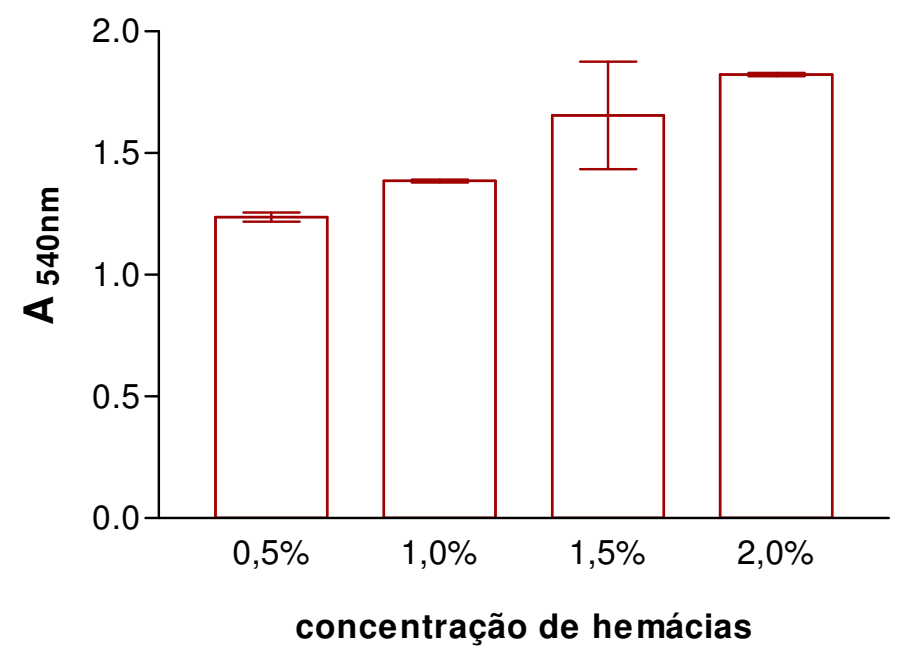

Figura 5. Medida da quantidade de hemoglobina livre por meio da absorbância a $540 \mathrm{~nm}$ das suspensões de eritrócitos em diferentes concentrações incubadas V/V com água destilada por $1 \mathrm{~h}$ a $37^{\circ} \mathrm{C}$. 
A partir destes dados, avaliou-se o comportamento dos isolados padrões U4-41 e C3888. Como a $\alpha$-hemolisina é liberada no meio de cultivo utilizou-se o sobrenadante da cultura bacteriana. Já no caso da toxina enterohemolítica investigou-se a fração do cultivo bacteriano que promovia maior lise dos eritrócitos. Assim foram testados o sobrenadante e o precipitado bacteriano rompido com polimixina. Pode-se observar na figura 6 que a fração correspondente ao precipitado se mostrou mais potente na lise celular que 0 sobrenadante de cultivo.

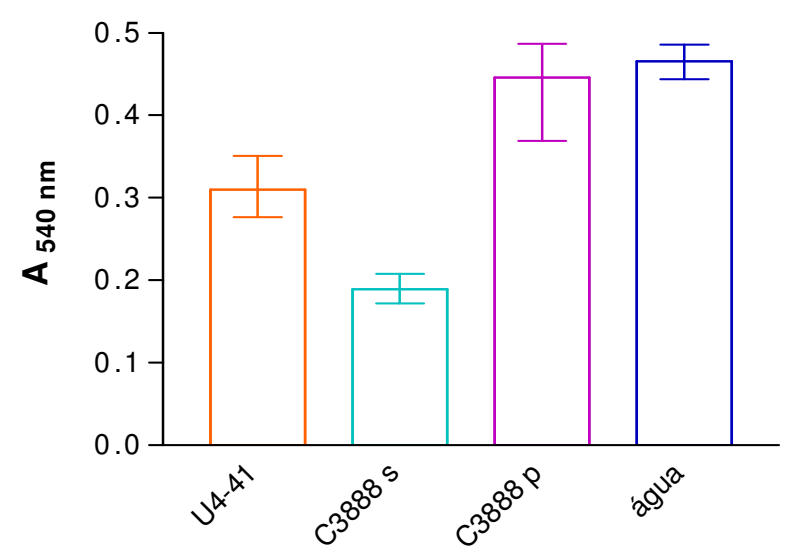

Figura 6. Quantidade de hemoglobina liberada medida por absorbância a $540 \mathrm{~nm}$ para os isolados controles de a-hemolisina (U4-41) e enterohemolisina (C3888) nas frações de sobrenadante (s) e precipitado $(p)$.

\subsubsection{Avaliação da expressão de enterohemolisina nos diferentes meios de cultivo}

Depois de padronizados os ensaios de hemólise em meio líquido, cultivou-se os isolados de interesse nos três meios escolhidos, TSB, meio Mínimo e Evans para realização dos experimentos. Pela análise dos resultados mostrados na figura 7 , observa-se que, com exceção de TSB, os meios mínimos e Evans promovem lise eritrocítica em diferentes intensidades. 


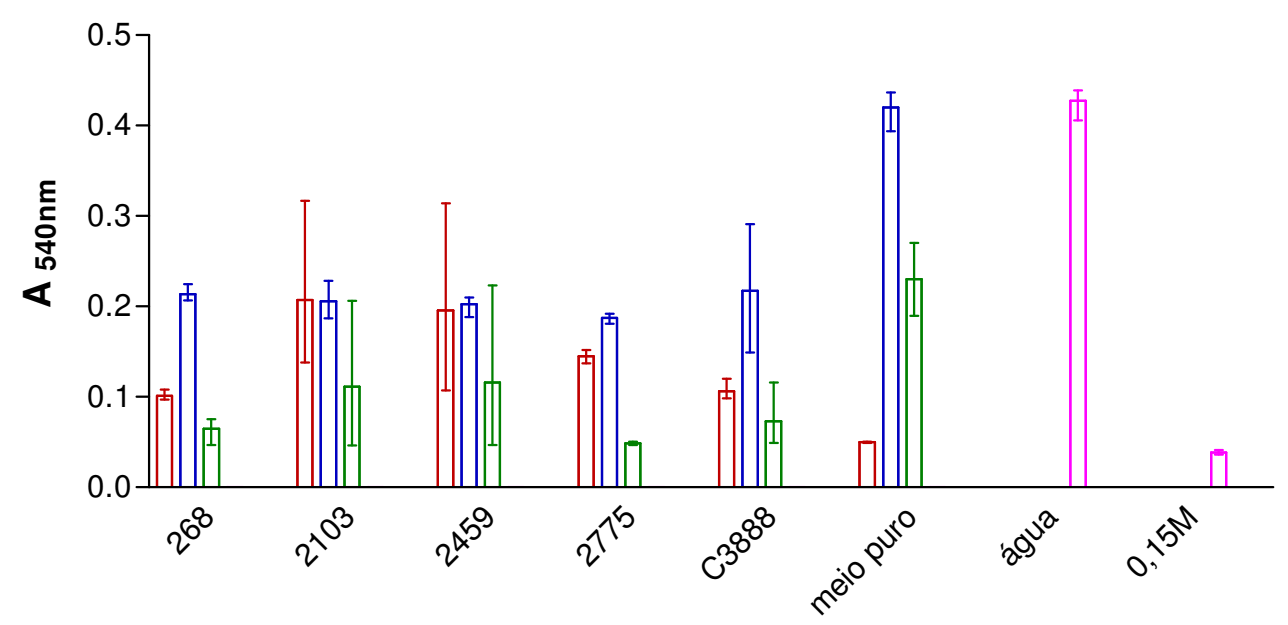

Figura 7. Ensaio de hemólise líquida representativa da liberação de hemoglobina provocada pelos isolados medida através da absorbância a $540 \mathrm{~nm}$. Isolados 268, 2103, 2459, 2775 e C3888 (EHly+) quando pré-cultivados em TSB (vermelho), meio mínimo (azul) e meio de Evans (verde) e os controles água e salina $0,15 \mathrm{M}$ (magenta).

\subsubsection{Interferência da lactose na atividade hemolítica}

O meio mínimo mostrou uma expressão diferenciada da toxina, comparando sua composição com os outros meios estudados, a lactose como fonte de carboidrato pareceu exercer influência na expressão toxigênica. Sendo assim, testou-se a interferência da lactose alterando a composição de carboidrato do meio TSB. Com esse experimento observou-se que a presença de lactose no meio TSB inibe a hemólise (Figura 8). 


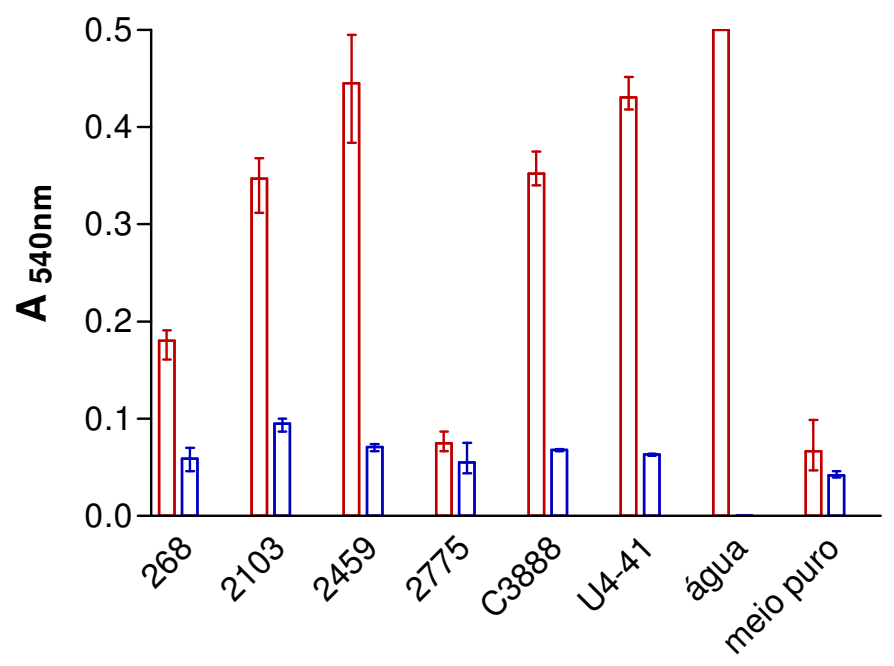

Figura 8. Quantidade de hemoglobina liberada medida por absorbância a $540 \mathrm{~nm}$ para os isolados enterohemolíticos 2103, 2459, 2775 e C3888 (EHly+), para o isolado negativo 268 e para o isolado $\alpha-$ hemolítico (U4-41) testados em TSB com glicose $2 \%$ (vermelho) ou lactose $2 \%$ (azul).

\subsection{Produção de anticorpo policlonal}

Como os experimentos de hemólise líquida foram inconclusivos e não reprodutíveis foi necessária à obtenção de anticorpos policlonais. Primeiramente, definiu-se que a atividade hemolítica estava na fração correspondente ao sobrenadante do cultivo bacteriano (Figura 9). Esta fração foi utilizada na imunização de ratos para obtenção de um anticorpo policlonal. 


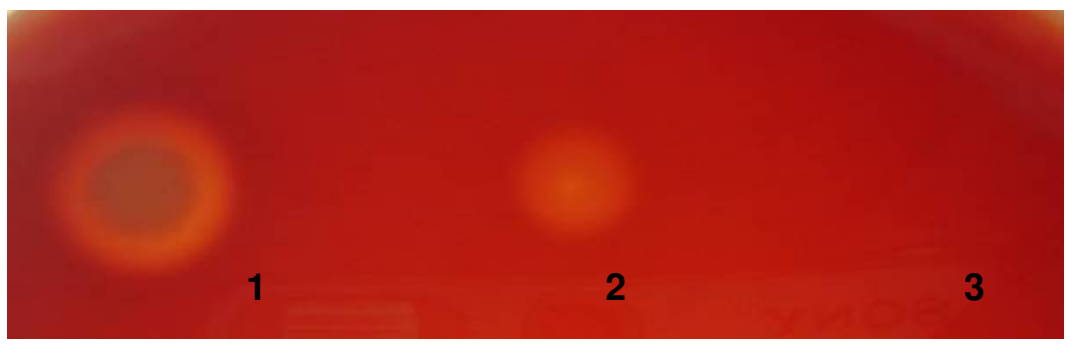

Figura 9. Perfil hemolítico do isolado C3888: 1. colônia bacteriana, 2. sobrenadante de cultivo, 3. precipitado rompido.

O perfil da resposta imune foi verificado por ensaios de immunoblotting. Observou-se que reatividade deste soro era bastante complexa, sendo assim fez-se necessária a adsorção do soro com um isolado bacteriano não hemolítico. Na figura 10 observa-se que o soro imune não reconhece no isolado 268 uma banda de mobilidade relativa na faixa de massa molecular entre 35 - 39 kDa.

A

B
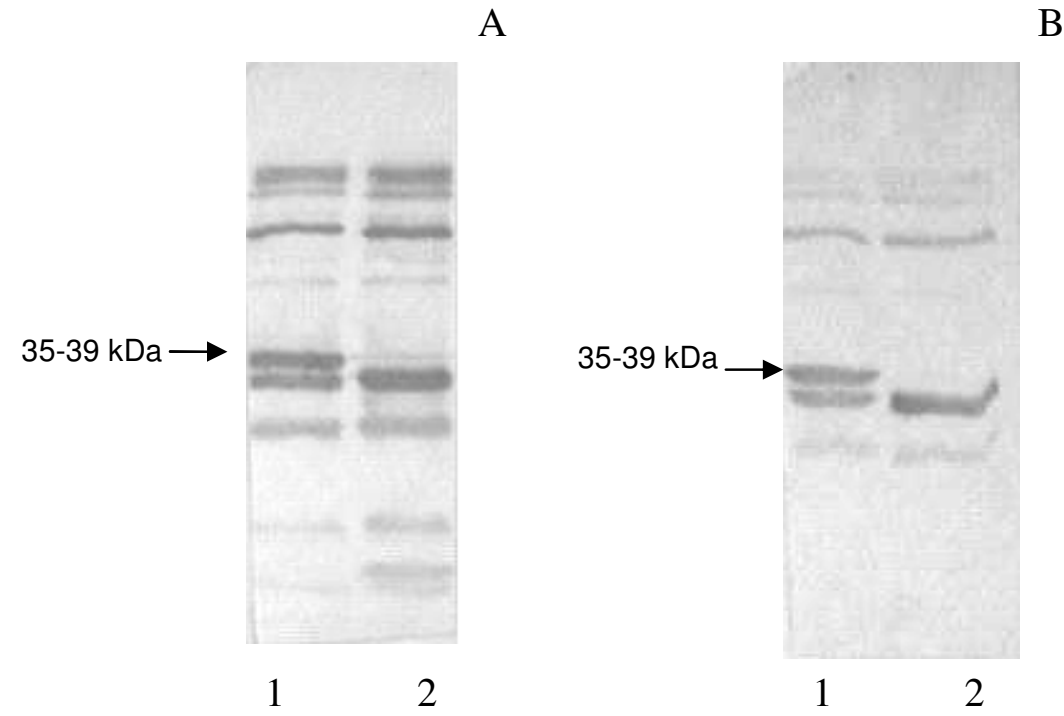

Figura 10. Reatividade das membranas de nitrocelulose contendo frações protéicas dos sobrenadantes bacterianos dos isolados: 1. C3888, 2. 268. As membranas foram incubadas com (A) soro imune não adsorvido e (B) soro imune adsorvido diluídos em 1:1.000 seguida da incubação com soro de cabra anti-rato conjugado a peroxidase. 


\subsection{Padronização de ensaio imunoenzimático para diferenciação entre isolados hemolíticos e não hemolíticos}

Ensaios de padronização foram realizados a fim de determinar a melhor diluição do soro para diferenciar os isolados não produtores dos produtores de enterohemolisina. Para essa padronização, as placas foram sensibilizadas com sobrenadante ou o precipitado rompido com polimixina ou as próprias bactérias fixadas e diluições do soro de 1:50 a 1:3.200 (figura 11).

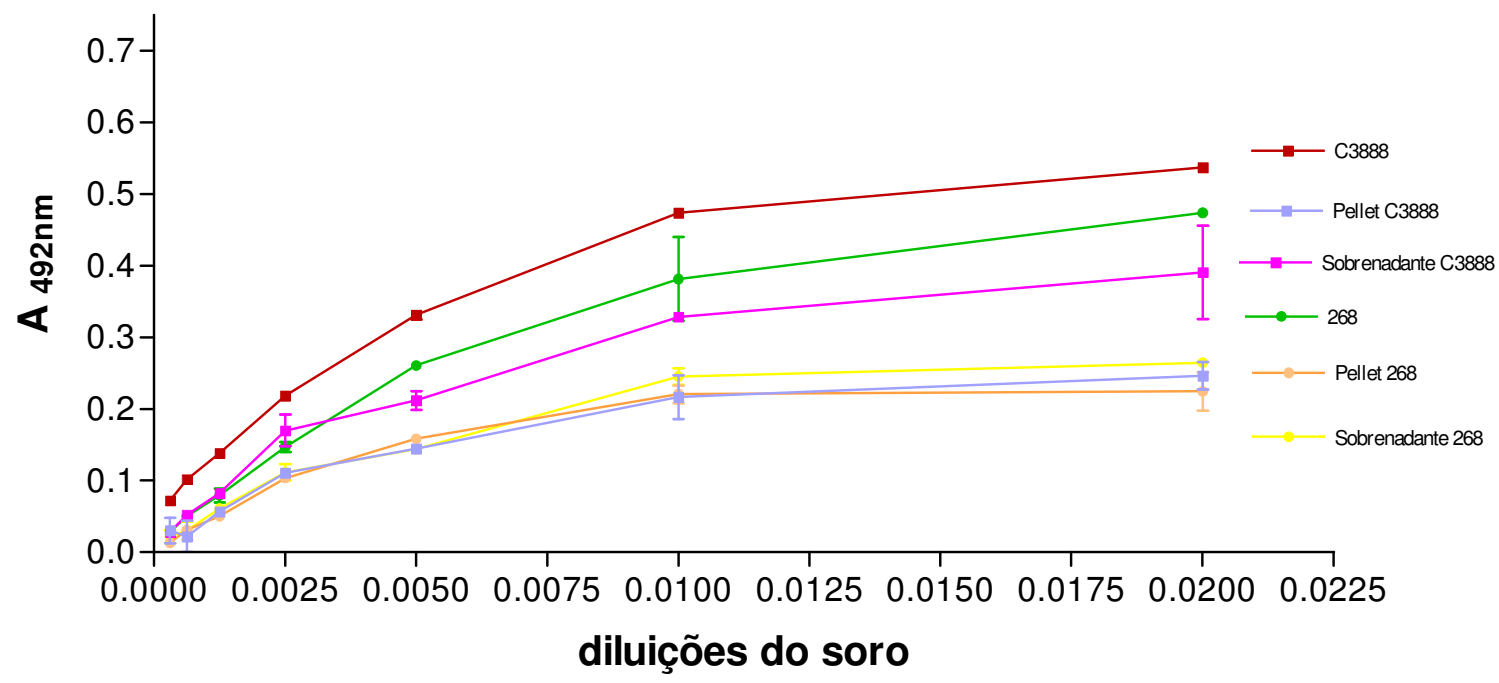

Figura 11. Placa de ELISA sensibilizada com $100 \mu \mathrm{L}$ de sobrenadante ou precipitado ou bactérias fixadas dos isolados controles: produtor de enterohemolisina (C3888) e não produtor (268). Foram incubadas com soro imune em diversas diluições e soro de cabra anti-rato conjugado a peroxidase (1:10.000). Como solução cromógena foi utilizado OPD + $\mathrm{H}_{2} \mathrm{O}_{2}$ e leitura realizada a $492 \mathrm{~nm}$.

Nas diluições do soro de 1:50 ou 1:100 ou 1:200 houve diferenças no reconhecimento entre $o$ isolado enterohemolítico padrão e 0 isolado não produtor. Quando se testou as bactérias íntegras fixadas na placa de poliestireno com solução de paraformaldeído $2 \%$ observou-se baixa diferenciação nos valores de densidade ótica obtida entre os isolados enterohemolíticos e não enterohemolíticos (Figura 12). 
A
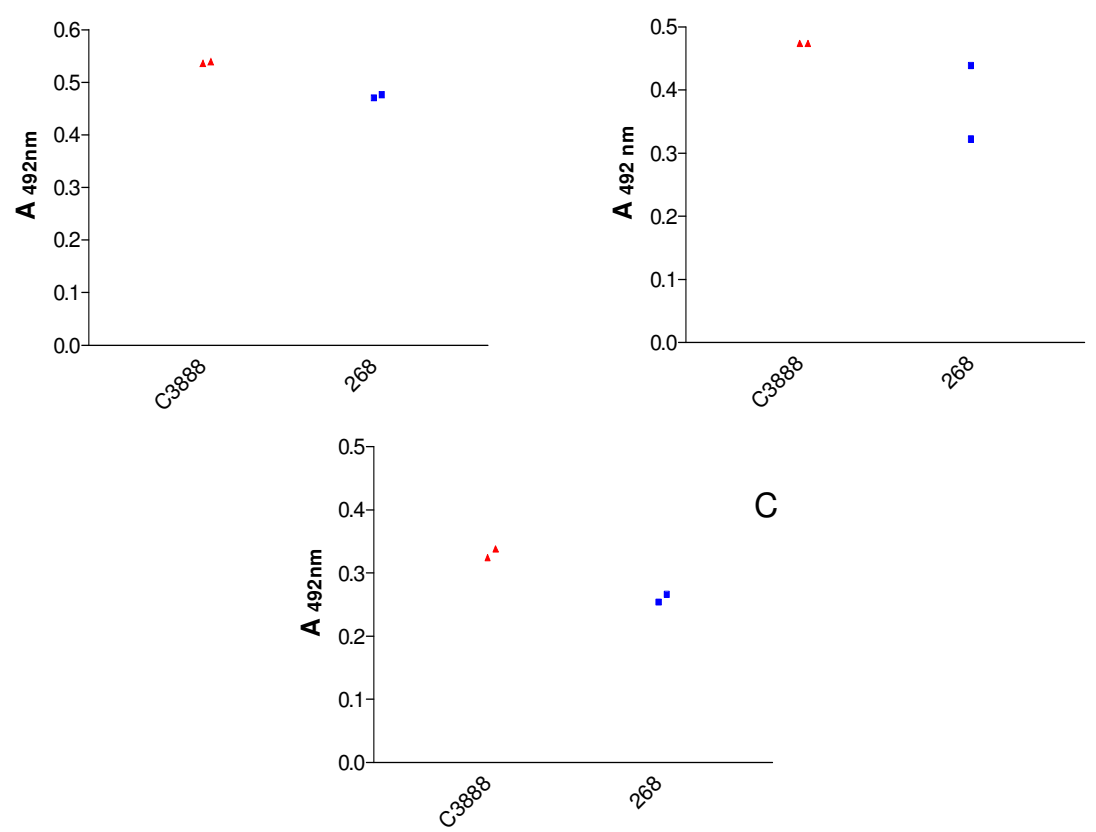

Figura 12. Placa de ELISA sensibilizada com os isolados bacterianos fixados com paraformaldeído. O isolado produtor de enterohemolisina C3888 $(\mathbf{\Delta})$ e 0 não produtor 268 ( $)$ e incubadas com soro imune nas diluições (A) 1:50, (B) 1:100 e (C) 1:200 respectivamente e soro de cabra anti-rato conjugado a peroxidase (1:10.000). Como solução cromógena foi utilizado $\mathrm{OPD}+\mathrm{H}_{2} \mathrm{O}_{2}$ e leitura realizada a $492 \mathrm{~nm}$.

Em seguida foi analisada a fração de sobrenadante dos isolados C3888 e 268. Conforme dados de dispersão ilustrados na figura 13, nota-se melhor diferenciação entre os isolados enterohemolíticos e não enterohemolíticos na diluição do soro de 1:200 (Figura 13C). 
A
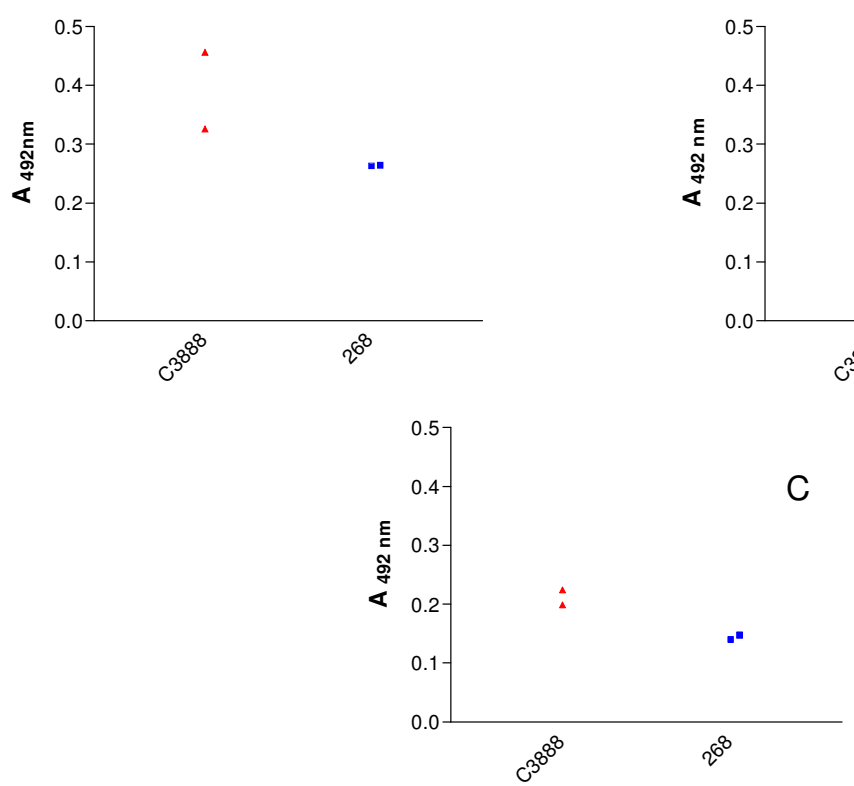

B

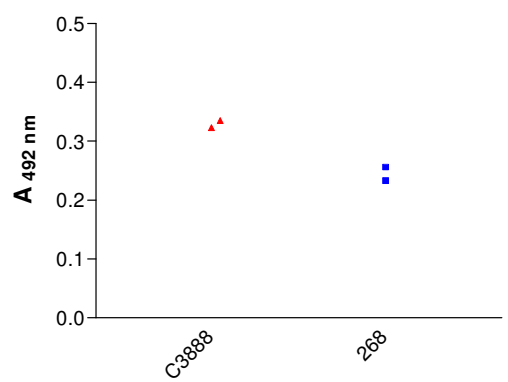

C

Figura 13. Placa de ELISA sensibilizada com $100 \mu \mathrm{L}$ de sobrenadante dos isolados bacterianos produtor de enterohemolisina $\mathrm{C} 3888$ ( $)$ e não produtor 268 (-) incubadas com soro imune em nas diluições (A) 1:50, (B) 1:100 e (C) 1:200 e soro de cabra anti-rato conjugado a peroxidase (1:10.000). Como solução cromógena foi utilizado OPD $+\mathrm{H}_{2} \mathrm{O}_{2}$ e leitura realizada a 492 $\mathrm{nm}$.

O ensaio imunoenzimático de atividade hemolítica permitiu a discriminação dos isolados enterohemolíticos dos não hemolíticos, mostrando grupos significativamente distintos $\left(p=0,0185 R^{2}=0,9634\right.$, figura 14). Por este ensaio determinou-se também como 0,09 a densidade ótica de corte para quantificação dos isolados enterohemolíticos. 


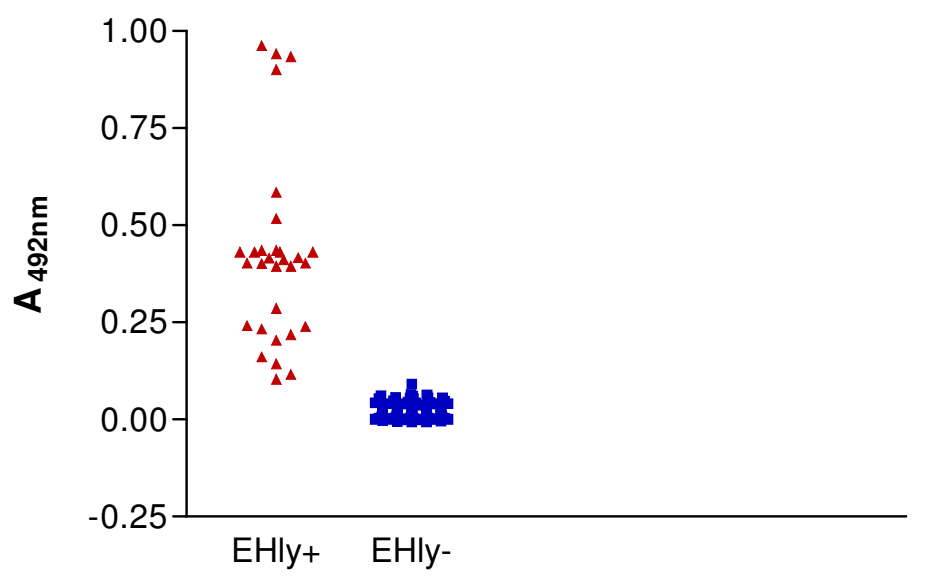

Figura 14. Placa de ELISA sensibilizada com sobrenadantes dos isolados bacterianos $(100 \mu \mathrm{L})$ produtores de enterohemolisina $(\boldsymbol{\Lambda})$ e não produtores (-) e incubadas com soro imune (1:200) e soro de cabra anti-rato conjugado a peroxidase (1:10.000). Como solução cromógena foi utilizado OPD $+\mathrm{H}_{2} \mathrm{O}_{2}$ e leitura realizada a $492 \mathrm{~nm}$.

5.8 Avaliação da interferência de componentes dos meios de cultivo na expressão toxigênica avaliada por ensaio imunoenzimático

Uma primeira avaliação da interferência de componentes dos meios de cultivo na expressão toxigênica foi determinada pelo ensaio de hemólise em placas de ágar sangue de carneiro em que se detectou visualmente atividade hemolítica em $3 \mathrm{~h}$ para as produtoras de $\alpha$-hemolisina e $24 \mathrm{~h}$ para as enterohemolíticas (Tabela 5 e Figura 3). 
Para quantificar a aparente modulação da expressão toxigênica em função da concentração de carboidrato, os sobrenadantes de cultivo de cinco isolados $(1887,2062,2103,2459,4192)$ foram submetidos a ensaios de ELISA. Por esta análise, os isolados 2062 e 4192 que apresentaram modulação na expressão da toxina de acordo com a concentração de lactose no meio de cultivo enquanto os demais não mostraram nenhuma alteração. Esta atividade foi detectada quando os isolados foram cultivados em meio contendo $0,25 \%$ de lactose (Figura 15).
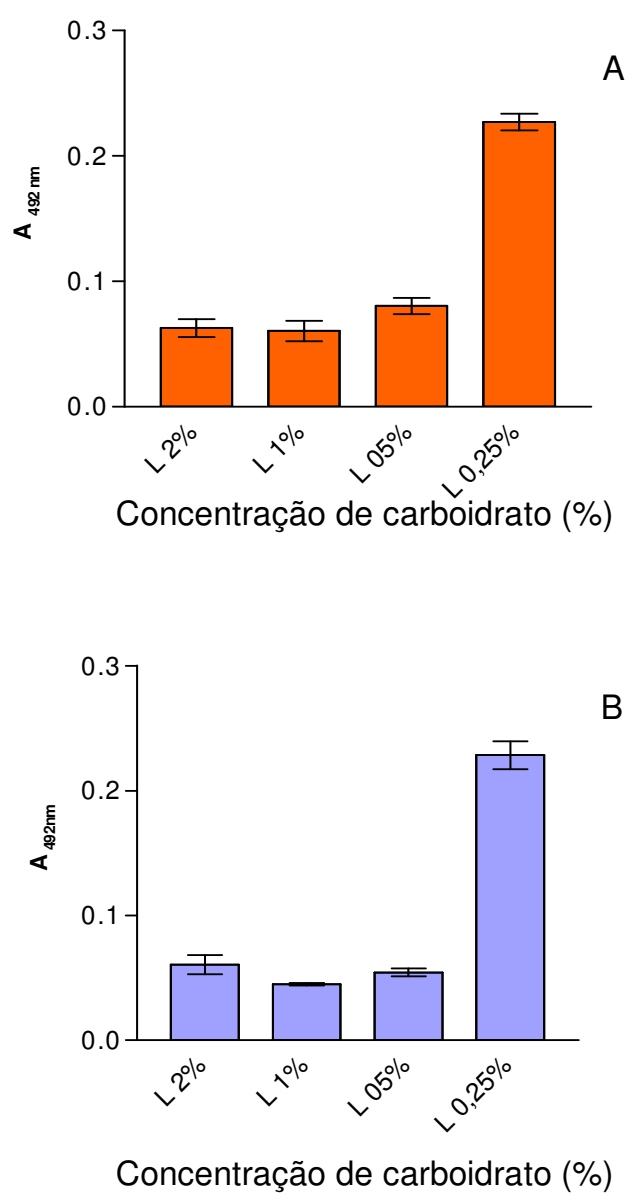

Figura 15. Placa de ELISA sensibilizada com sobrenadantes dos isolados bacterianos (A) 2062, (B) 4192 cultivados em TSB em diferentes concentrações de glicose $(G)$ ou lactose $(L)$ e incubadas com soro imune $(1: 200)$ e soro de cabra anti-rato conjugado a peroxidase (1:10.000). Como solução cromógena foi utilizado OPD $+\mathrm{H}_{2} \mathrm{O}_{2}$ e leitura realizada a $492 \mathrm{~nm}$. 


\subsection{Inibição da atividade hemolítica pelo soro policlonal}

Foram também realizados ensaios de inibição da hemólise do isolado controle (C3888) com o anticorpo policlonal produzido. Os testes de inibição em placa de ágar sangue de carneiro não tiveram sucesso já que qualquer isolado positivo ou negativo incubado com o soro produzia halo de hemólise sugerindo que o próprio soro estaria promovendo lise das hemácias. O mesmo foi observado em ensaio de ELISA já que a placa quando sensibilizada com o sobrenadante de cultivo junto com o soro tinham resultado falso positivo, indicando que moléculas de anticorpo estariam aderindo à placa e sendo reveladas pelo conjugado.

\subsection{Associação dos isolados enterohemolíticos a componentes de Matriz Extracelular}

Como a enterohemolisina é uma toxina formadora de poros e liga-se a diferentes células epiteliais e endoteliais avaliou-se a capacidade de adesão das proteínas secretadas de EPECa produtoras ou não de EHly a diferentes componentes de matriz extracelular. Os resultados foram dados pela análise das densidades óticas obtidas. Conforme mostrado na tabela 7 a adesão é preferencial a fibronectina celular. No entanto, sem qualquer correlação entre a produção ou não de EHly, alguns isolados apresentaram adesão também a colágeno do tipo IV.

O isolado 2103 aderiu fortemente a todos componentes de matriz extracelular testados (Tabela 7). A mais forte interação ocorreu com as proteínas secretadas pelo isolado 2103 à fração F30 de fibronectina plasmática que corresponde ao domínio de ligação a heparina. 
Tabela 7: Adesão dos isolados de EPECa a componentes de matriz extracelular.

\begin{tabular}{ccccccccc}
\hline \multirow{2}{*}{$\begin{array}{c}\text { Isolados } \\
\text { bacterianos }\end{array}$} & Sorotipo & \multicolumn{9}{c}{ Componentes de matriz extracelular } \\
\cline { 3 - 8 } & & $\begin{array}{c}\text { Fibronectina } \\
\text { celular }\end{array}$ & $\begin{array}{c}\text { Fibronectina } \\
\text { plasmática }\end{array}$ & F30 & F45 & Laminina & Colágeno I & Colágeno IV \\
\hline 1224 & O25:H1 & + & - & - & - & - & - & - \\
2062 & O171:H48 & + & - & - & - & - & - & + \\
2103 & O26:H11 & + & + & ++ & + & + & + & + \\
2117 & ONT:H5 & + & - & - & - & - & - & - \\
2459 & O26:H11 & + & - & - & - & - & - & + \\
2775 & O113H19 & + & - & - & - & - & - & - \\
3160 & O110:H- & + & - & - & - & - & - & - \\
C3888 & O26:H- & + & - & - & - & - & - & + \\
268 & O49:H6 & - & - & - & - & - & - & + \\
531 & O1:H45 & - & - & - & - & - & - & - \\
589 & O5:H2 & - & - & - & - & - & - \\
1719 & O1:H45 & - & - & - & - & - & - & - \\
2034 & ONT:H10 & - & - & - & - & - & - & - \\
2923 & O34:H6 & - & - & - & - & - & - & - \\
3392 & O124:H11 & - & - & - & - & - & - & - \\
3977 & ONT:H45 & - & - & - & - & - & - & - \\
4013 & O88:H- & - & - & - & - & - & - \\
4132 & O51:H48 & - & - & - & - & - \\
& & - & - & - & - & & - \\
\end{tabular}

++ adesão muito forte 
Além da avaliação da adesão, foi feita análise estatística dos dados (figura 16), que mostra correlação entre adesão de isolados produtores de EHly à fibronectina celular e não adesão dos isolados não produtores a esse componente de matriz extracelular.

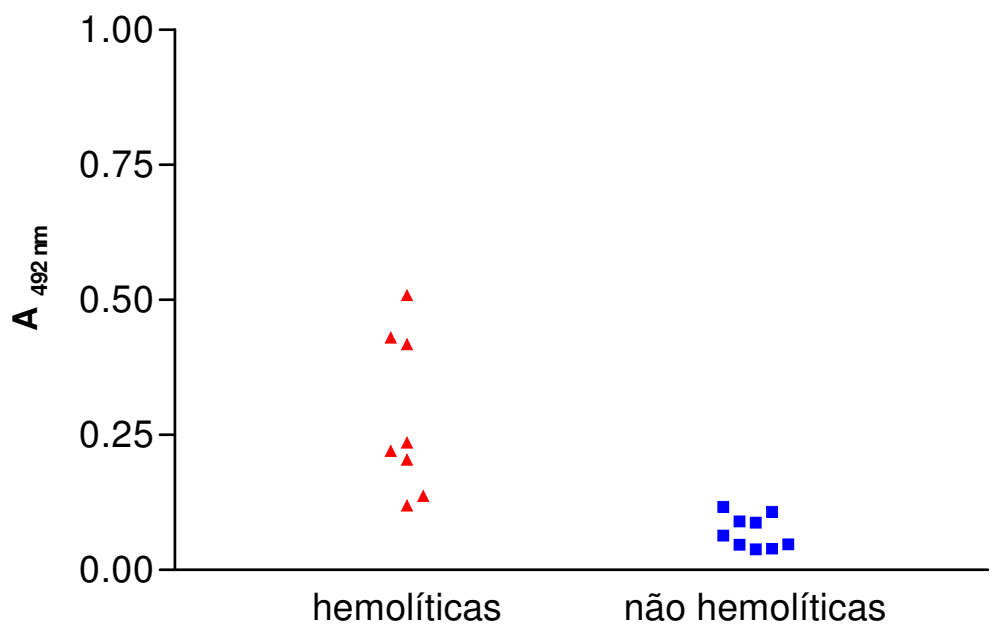

Figura 16. Placa de ELISA sensibilizada com fibronectina celular incubadas com $20 \mu \mathrm{g}$ de sobrenadante concentrado dos isolados bacterianos produtores de enterohemolisina $(\boldsymbol{\Lambda})$ e não produtores $(\square)$ e seguida da reação com soro imune (1:5.000) e soro de cabra anti-rato conjugado a peroxidase (1:10.000). Como solução cromógena foi utilizado OPD $+\mathrm{H}_{2} \mathrm{O}_{2}$ e leitura realizada a $492 \mathrm{~nm}$. 


\section{DISCUSSÃo}

Diversos trabalhos em diferentes países vêm mostrando que EPECa está significativamente associada a casos diarréicos endêmicos (VIEIRA et al., 2001; DULGER et al., 2003; WANI et al., 2006) ou mesmo surtos diarréicos (YATSUNAGl et al., 2002; JENKINS et al., 2003). Tal prevalência tem sido um argumento bastante consistente para se considerar EPECa como um patógeno emergente, capaz de colonizar a mucosa intestinal e causar diarréia (SCALETSKY et al.; 2002, TRABULSI et al.; 2002, FRANZOLIN et al.; 2005).

Nestes patógenos, além da capacidade de formar a lesão histopatológica típica no epitélio do intestino, denominada de lesão A/E (NATARO; KAPER, 1998), não foi descrito nenhum outro fator de virulência exclusivo de EPECa. Ao contrário, têm sido encontrados fatores de virulência comuns a outros patotipos.

Dentre esses, as toxinas são os mais freqüentes fatores de virulência encontrados e o gene ehx que codifica a EHly, tem sido associado tanto a isolados de EPEC e STEC humanos como a de animais (NATARO, KAPER, 1998; LEOMIL et al., 2005; AIDAR-UGRINOVICH et al., 2007). Com isso temse estabelecido relações entre os patotipos EPECa e STEC utilizando o fator de virulência EHly como parâmetro.

$\mathrm{Na}$ busca de fatores de virulência próprios de EPECa decidiu-se pesquisar a atividade hemolítica em 90 isolados de estudo epidemiológico realizado em Salvador (BA) (BUERIS et al., 2007). Apesar da presença do gene Ehly ter sido encontrado somente em dois isolados: 2103 e 2459, ambos pertencentes ao sorotipo $\mathrm{O} 26: \mathrm{H} 11$, a prevalência de $\alpha$-hemólise e enterohemólise foi de 2,7\% (2) e 5,4\%, (5) respectivamente. Dentre os isolados hemolíticos, os $\alpha$-hemolíticos pertencem aos sorotipo 0111:H38, O34:H6 e O34: $\mathrm{H}$ - e nos enterohemolíticos encontram-se isolados dos sorotipos O26:H11, O25:H1, ONT:H5, O113:H19 e O110:H-. Aidar-Ugrinovich et al. (2007) encontraram atividade de EHly em EPECa de diversos sorotipos isolados de 
bovinos no Brasil, também Cookson et al. (2007) mostraram atividade hemolítica em isolados de EPECa e STEC isolados de diversas origens.

Existe um consenso de que o nível de expressão de toxinas é dependente do meio em que a bactéria é cultivada. Em 1983, O’Brien et al. descreveram três categorias de $E$. coli produtora da toxina de Shiga compreendendo: baixa, moderada e alta produção da toxina. Após esta descrição, diferentes meios de cultivo ou de enriquecimento foram empregados em diagnóstico de STEC com o objetivo de detectar melhores níveis de Stx. Essa assertiva pode ser confirmada tanto para Stx (ROCHA; PIAZZA, 2007) como para plasmid encoded toxin (pet) produzida por $E$. coli enteroagregativa (EAEC) (VILHENA-COSTA et al., 2006).

A variação na atividade hemolítica de cepas de STEC $\beta$-hemolíticas foi observada previamente por Chart et al. (1998). Para avaliar, se há uma variação na atividade hemolítica dos isolados estudados empregou-se os meios Mínimo, Evans e TSB. Esta escolha baseou-se na composição de cada meio em função da fonte protéica e de carbono. O meio mínimo mostrou uma expressão diferenciada da toxina, comparando sua composição com os outros meios estudados, a lactose como fonte de carboidrato e a caseína como fonte protéica sugeriam interferir na expressão toxigênica. Sendo assim, testou-se a lactose alterando a composição e concentração de carboidrato dos meio TSB, Evans e meio mínimo e diferentes concentrações de caseína no meio mínimo.

Os isolados 300, 2034, 2062, 4013 e 4192 realmente apresentaram atividade hemolítica diferenciada dependente da concentração de carboidrato. Esta variação na atividade hemolítica também foi observada em relação a concentração de caseína, como fonte protéica, evidenciada principalmente no isolado 3160. Recentemente, Cooksoon et al. (2007) descreveram diferentes fenótipos enterohemolíticos em função dos seis subtipos obtidos por PCR-RFLP do gene ehxA em isolados de STEC e EPECa, tais variações poderiam explicar nossos resultados que, podem ser atribuídos a alterações de expressão ou secreção protéica, mas no entanto, o real mecanismo ainda é desconhecido. 
Tentou-se quantificar as variações observadas nos experimentos de hemólise sólida em ensaios de hemólise líquida (BHAKDI et al., 1986). O meio mínimo mostrou uma expressão diferenciada da toxina, a lactose como fonte de carboidrato pareceu exercer influência na expressão toxigênica. No entanto, observou-se interferência do próprio meio de cultivo na lise das hemácias. $O$ meio que menos interferiu na lise dos eritrócitos foi o TSB, que teve então sua composição e concentração de carboidrato alterada para verificação e quantificação dos diversos fenótipos hemolíticos anteriormente observados. Entretanto, tal metodologia não foi adequada para cumprir seus fins já que os próprios componentes dos meios promoviam ou impediam a lise das hemácias além da falta de reprodutibilidade do método.

Buscou-se então outra estratégia para quantificar a atividade EHly nos isolados de EPECa. Produziu-se um soro imune contra o sobrenadante concentrado da amostra protótipo C3888 (BEUTIN et al., 1989) cujo soro foi adsorvido com um isolado de EPECa não produtor de EHly. Nos ensaios de immunoblotting observou-se que este soro deixou de reconhecer no isolado não-EHly, uma proteína de mobilidade relativa na faixa de massa molecular entre 35 - 39 kDa, sugerindo que este soro esteja diferenciando isolados produtores e não produtores de EHly.

Ensaios de inibição da hemólise do isolado controle com o anticorpo policlonal foram realizados, no entanto, os testes em placa de ágar sangue de carneiro não tiveram sucesso já que qualquer isolado positivo ou negativo incubado com o soro produzia halo de hemólise sugerindo que o próprio soro estaria promovendo lise das hemácias. O mesmo foi observado em ensaio de ELISA já que a placa quando sensibilizada com o sobrenadante de cultivo junto com o soro tinham resultado falso positivo, indicando que moléculas de anticorpo estariam aderindo à placa e sendo reveladas pelo conjugado.

A padronização de um ELISA quantitativo utilizando-se diversos isolados EHly positivos e negativos cultivados em TSB permitiu uma análise estatística confiável onde foram observados dois grupos significativamente distintos $(p=$ 
$\left.0,0185 R^{2}=0,9634\right)$. A modulação da atividade hemolítica observada nos isolados 2062 e 4192 foi determinada qualitativamente em placa de ágar sangue e quantitativamente por ELISA. As variações na atividade hemolítica foram observadas principalmente quando os isolados foram cultivados em meio Mínimo ou TSB, que diferem na fonte e concentração de carboidrato. Observou-se que nas menores concentrações testadas a atividade hemolítica foi maior. A comprovação desta modulação por ELISA só será possível quando for estabelecido um padrão de corte das densidades óticas dos isolados não produtores de enterohemolisina cultivados nos meios mínimo e Evans analisando-se todos os isolados que apresentaram variação na atividade hemolítica em placa de ágar sangue.

No entanto, quando se nota que a quantidade de açúcar aumenta a expressão toxigênica, surge a hipótese de existir uma modulação dos níveis de AMPc dependente da concentração de carbono (LEHMACHER; BOCKEMÜHL, 2007). Em relação a caseína, parece que altas concentrações dessa proteína no meio de cultivo deva estar reprimindo a atividade hemolítica de alguns isolados no entanto, os mecanismos envolvidos nessa modulação ainda não são conhecidos e serão os próximos objetivos desse estudo. Bactérias de modo geral podem usar toxinas hemolíticas como mecanismo para conseguir nutrientes como o ferro, por exemplo, que é um fator limitante no crescimento bacteriano. A regulação da expressão gênica de estreptolisina $S$ de $S$. pyogenes é um sistema reprimido pela quantidade de ferro no ambiente (GRIFFITHS et al., 1988) assim, uma hipótese plausível para explicar os resultados observados, deve considerar a composição da caseína hidrolisada comercialmente adquirida que contém $3 \mathrm{mg}$ de ferro por grama de caseína. Tal concentração de ferro poderia então estar gerando a repressão da atividade hemolítica observada (SRITHARAN et al., 2007).

Extrapolando este raciocínio para uma situação in vivo, este fator de virulência que até então não seria muito relevante na patogênese, poderia se tornar mais expressivo. Esses dados sugerem que esta modulação é vantajosa 
para as EPECa porque as tornam mais eficientes na competição com outros microrganismos do lúmen intestinal.

Durante todo este estudo diferentes ferramentas foram utilizadas na detecção de EHly. Para detecção do gene ehx nos isolados com fenótipo enterohemolítico, foi usada metodologia descrita por Beutin et al. (2004) em que os iniciadores foram desenhados a partir de seqüência do p0157 de EHEC, o que explica o baixo índice de amplificação do gene nos isolados estudados.

O ensaio padrão para detecção de atividade hemolítica foi feito pela observação de halo de hemólise em placas de ágar sangue. Essa metodologia se mostrou confiável e reprodutível na observação de lise de eritrócitos, porém é insuficiente na quantificação de toxina. Dois métodos foram aplicados na quantificação da toxina, no entanto as limitações do ensaio de hemólise líquida anteriormente mencionado e no ELISA padronizado foi definido somente o cut off para isolados cultivados em TSB. Esse valor de corte não pode ser utilizado quando os isolados são cultivados nos outros meios, pois os valores de DO observados para o isolado controle C3888 variou de 0,8 a 1,8 quando este foi cultivado nos diferentes meios analisados (dados não mostrados). Sendo assim, para definir o ELISA como método quantitativo, será necessário estabelecer uma DO de corte para cada um dos meios de cultivo.

As hemolisinas produzidas tanto por bactérias Gram positivas como por Gram negativas, ao contrário de outras toxinas, não são internalizadas pelas células alvo, mas atuam sobre as membranas celulares não apenas de eritrócitos, mas também de fibroblastos, células do miocárdio, plaquetas, monócitos, granulócitos e células endoteliais (JURGENS et al., 2002).

A ligação da bactéria a um ou mais componentes de matriz extracelular como colágeno I e IV, laminina, fibronectinas celular e plasmática seriam indícios de que essas moléculas estariam sendo usadas como substrato de adesão facilitando a colonização do hospedeiro pela bactéria patogênica (LOWRANCE et al., 1988). Nos ensaios de adesão aos componentes de matriz extracelular observou-se que proteínas secretadas por isolados que expressam 
EHly aderiram a fibronectina celular, esses dados sugerem fortemente a correlação entre a expressão de EHly e ligação a fibronectina, uma vez que os isolados não hemolíticos não apresentaram tal adesão. Além disso, o isolado 2103 (O26:H11) aderiu fortemente a todos os componentes de matriz extracelular testados indicando que este isolado apresenta proteína (s) com característica (s) de adesina (s). Isso já foi observado para outros patógenos, como é o caso da a $\alpha$-toxina produzida por $S$. aureus que liga-se aos componentes de matriz extracelular utilizando a $\beta 1$ integrina como seu receptor (LIANG, JI, 2006). Já uma lipoproteína de superfície de Leptospira interrogans (Lsa24) adere fortemente a laminina que é um componente presente, tanto no tecido epitelial como endotelial, além de outras proteínas secretadas e de adesão já descritas nesse mesmo patógeno (BARBOSA et al., 2006; MATSUNAGA et al., 2003; CHOY et al., 2007).

O conjunto dos resultados obtidos nos permite afirmar que apesar da baixa prevalência de EHly nos isolados de EPECa, novas características fenotípicas foram encontradas no desenvolvimento deste trabalho, tais como a modulação da expressão da atividade hemolítica em função da concentração de carboidrato e de proteína, bem como a adesão à fibronectina celular. 


\section{REFERÊNCIAS BIBLIOGRÁFICAS}

AIDAR-UGRINOVICH, L.; BLANCO, J.; BLANCO, M.; BLANCO J.E.; LEOMIL L.; DAHBI G.; MORA A.; ONUMA D.L.; SILVEIRA W.D.; PESTANA DE CASTRO A.F. Serotypes, virulence genes, and intimin types of Shiga toxinproducing Escherichia coli (STEC) and enteropathogenic E. coli (EPEC) isolated from calves in São Paulo, Brazil. Int. J. Food Microbiol., v. 20, p. 297-306, 2007.

ARAUJO J.M.; TABARELLI G.F; ARANDA K.R; FABBRICOTTI S.H; FAGUNDES-NETO U.; MENDES C.M; SCALETSKY I.C. Typical enteroaggregative and atypical enteropathogenic types of Escherichia coli are the most prevalent diarrhea. J. Clin. Microbiol., v. 45, p. 3396-3399, 2007.

BARBOSA, A.S.; ABREU, P.A.E.; NEVES, FERNANDA O.; ATZINGEN, M.V.; WATANABE, M.M.; VIEIRA, M.L.; MORAIS, Z.M.; VASCONCELLOS, S.A.; NASCIMENTO, A.L.T.O. A newly identified leptospiral adhesin mediates attachment to laminin. Infect. Immun., v. 74, p. 6356-6364, 2006.

BARRETO, M. L.; MILROY, C. A; STRINA, A.; PRADO, M. S.; LEITE, J. P.; RAMOS, E. A.; RIBEIRO, H.; ALCANTARA-NEVES, N. M.; TEIXEIRA, M. G.; RODRIGUES, L. C.; RUF, H.; GUERREIRO, H.; TRABULSI, L. R. Communitybased monitoring of diarrhea in urban Brazilian children: incidence and associated pathogens. Trans. R. Soc. Trop. Med. Hyg., v.100, p. 234-242, 2005.

BEUTIN, L. The different hemolysins of Escherichia coli. Med. Microbiol. Immunol., v.180, p. 167-182, 1991.

BEUTIN, L.; BODE, L.; ÖZEL, M.; STEPHAN, R. Enterohemolysin production is associated with a temperate bacteriophage in Escherichia coli serogroup O26 strains. J. Bacteriol., v.172, p.6469-6475, 1990. 
BEUTIN, L.; MONTENEGRO, M.; ØRSKOV, I.; ØRSKOV, F.; PRADA, J.; ZIMMERMANN, S.; STEPHAN, R. Close association of verotoxin (shiga-like toxin) production with enterohemolysin production in strains of Escherichia coli. J. Clin. Microbiol., v.27, p.2559-2564, 1989.

BEUTIN L.; KRAUSE G.; ZIMMERMANN S.; KAULFUSS S.; GLEIER K. Characterization of Shiga toxin-producing Escherichia coli strains isolated from human patients in Germany over a 3-year period. J. Clin. Microbiol., v. 42, p. 1099-108, 2004.

BHAKDI, S.; MACKMAN, N.; NICAUD, J.M.; HOLLAND, I. B.; Escherichia coli hemolysin may damage target cell membranes by generating transmembrane pores. Infect. Immun., v. 52, p. 63-69, 1986.

BOCZEK L.A.; JOHNSON C.H.; RICE E.W.; KINKLE B.K. The widespread occurrence of the enterohemolysin gene ehlyA among environmental strains of Escherichia coli. FEMS Microbiol. Lett., v. 254, p. 281-284, 2006.

BRADFORD, M.M. A rapid and sensitive method for the quantization of microgram quantities of protein utilizing the principle of protein-dye binding. Anal. Biochem., v.7, p. 248-254, 1976.

BUERIS V.; SIRCILI M.P.; TADDEI C.R.; SANTOS M.F.; FRANZOLIN M.R.; MARTINEZ M.B.; FERRER S.R.; BARRETO M.L.; TRABULSI L.R. Detection of diarrheagenic Escherichia coli from children with and without diarrhea in Salvador, Bahia, Brazil. Mem. Inst. Oswaldo Cruz., v 6, 2007.

CAMPOS, L.C.; WHITTAM, T.S.; GOMES, T.A.T.; ANDRADE, J.R.C.; TRABULSI, L.R. Escherichia coli serogroup 0111 includes several clones of diarrheagenic strains with differents virulence properties. Infect. Immun,, v. 62, p. $3282-3288,1994$.

CHART H.; JENKINS C.; SMITH H.R.; HEDGES D.; ROWE B. Haemolysin production by strains of Verocytotoxin-producing Escherichia coli. Microbiology., v. 144, p. 103-107, 1998. 
CHOY, H.A.; KELLEY, M.M.; GHEN, T.L.; MOLLER, A.K.; MATSUNAGA, J.; HAAKE, D.A. Physiological osmotic induction of Leptospira interrogans adhesionÇ LigA and LigB bind extracellular matriz proteins and fibrinogen. Infect. Immun., v.12 PMDI: 17296754, 2007.

COOKSON A.L.; BENNETT J.; THOMSON-CARTER F.; ATTWOOD G.T. Molecular subtyping and genetic analysis of the enterohemolysin gene (ehxA) from Shiga toxin-producing Escherichia coli and atypical enteropathogenic $E$. coli. Appl. Environ. Microbiol., v. 73, p. 6360-6369, 2007.

DULGER, M. V.; FABRICOTTI, S. H.; BANDO, S. Y.; MOREIRA-FILHO, C. A.; FAGUNDES-NETO, U.; SCALETSKY, I. C. Atypical enteropathogenic Escherichia coli strains: phenotypic and genetic profiling reveals a strong association between enteroaggregative $E$. coli heat-stable enterotoxin and diarrhea. J. Infect. Dis., v. 188, p. 1685-1694, 2003.

ENGVALL, E.; PERLMANN, P. Enzyme-linked immunosorbent assay (ELISA): quantitative assay of immunoglobulin. Immunochem., v. 8, p. 871, 1971.

FASANO, A.; KAY, B. A.; RUSSELL, R. G.; MANEVAL, D. R.; LEVINE, M.M. Enterotoxin and citotoxin production by enteroinvasive Escherichia coli. Infect. Immun., v.58, p. 3717-23, 1990.

FINLAY, B. B.; FALKOW S. Common themes in microbial pathogenicity revisited. Microbiol. Mol. Biol. Rev., v.61, p. 136-169, 1997.

FRANZOLIN, M.R.; ALVES, R.C.B.; KELLER, R.; GOMES, T.A.T.; BEUTIN, L.; BARRETO, M.L.; MILROY, C.; STRINA, A.; RIBEIRO, H.; TRABULSI, L.R. Prevalence of diarrheagenic Escherichia coli in children with diarrhea in Salvador, Bahia, Brazil. Mem. Inst. Oswaldo Cruz., v.100, p. 359-363, 2005.

FIGUEIREDO P.M.; CATANI C.F.; YANO T. Thiol-independent activity of a cholesterol-binding enterohemolysin produced by enteropathogenic Escherichia coli. Braz. J. Méd. Biol. Res., v.36, p. 1495-1499, 2003. 
FIGUEIREDO P.M.; FURUMURA M.T.; AIDAR-UGRINOVICH L.; PESTANA DE CASTRO A. F.; PEREIRA F.G.; METZE I.L.; YANO T. Induction of apoptosis in Caco-2 and HT-29 human intestinal epithelial cells by enterohemolysin produced by classic enteropathogenic Escherichia coli. Lett. Appl. Microbiol., v. 45, p. 358-63, 2007.

GENY B.; POPOFF M;R. Bacterial protein toxins and lipids: pore formation or toxin entry into cells. Biol. Cell.,v. 98, p. 667-678, 2006.

JENKINS, C.; SMITH, H. R.; LAWSON, A. J.; WILLSHAW, G. A.; CHEASTY, T.; WHEELER, J. G.; TOMPKINS, D. S. Serotypes, intimin subtypes, and antimicrobial resistance patterns of atypical enteropathogenic Echerichia coli isolated in England from 1993 to 1996. Eur. J. Clin. Microbiol. Infect. Dis., v.25, p.19-24, 2003.

JÜRGENS, D.; ÖZEL, M.; TAKAISI-KIKUNI, N.; B. Production and characterization of Escherichia coli enterohemolysin and its effects on the structure of erythrocyte membranes. Cell. Biol. Internat., v. 26, p.175-186, 2002.

KAPER, J. B.; NATARO J. P.; MOBLEY H. L. Pathogenic Escherichia coli. Nat. Rev. Microbiol., v. 2, p. 123-140, 2004.

KAYSER, H. Über Bakterienhãmolysine, im Besonderen das Colilysin. Z. Hyg. Infektionskr., v. 42, p. 118-138, 1903.

LAEMMLI, U.K. Cleavage of structural proteins during the assembly of the head of bacteriophage T4. Nature, v. 227, p. 680-5, 1970.

LEHMACHER A.; BOCKEMUHL, J. L-Sorbose utilization by virulent Escherichia coli and Shigella: Different metabolic adaptation of pathotypes. Int. J. Med. Microbiol., v.297, p. 245-254, 2007. 
LEOMIL L.; PESTANA DE CASTRO A.F.; KRAUSE G.; SCHMIDT H.; BEUTIN L. Characterization of two major groups of diarrheagenic Escherichia coli $\mathrm{O} 26$ strains which are globally spread in human patients and domestic animals of different species. FEMS Microbiol. Lett., v. 15, p. 335-342, 2005.

LIANG, X.; JI, Y. Alpha-toxin interferes with integrin-mediated adhesion and internalization of Staphylococcus aureus by epithelial cells. Cel. Microbiol., v. 8, p. 1656-1668, 2006.

LOWRANCE, J.H.; HASTY, D.L.; SIMPSON, W.A. Adherence of Streptococcus sanguis to conformationally specific determinants in fibronectin. Infect. Immun., v. 56 , p. 2279-2285, 1988.

MATSUNAGA, J.; BAROCCHI, M. A.; CRODA, J.; YOUNG, T.A.; SANCHEZ, Y.; SIQUEIRA, I.; BOLIN, C.A.; REIS, M.G.; RILEY, L.W.; HAAKE, D.A; KO, A.I. Pathogenic Leptospira species express surface-exposed proteins belonging to the bacterial immunoglobulin superfamily. Mol. Microbiol., v. 49, p. 929-945, 2003.

NATARO, J. K.; KAPER, J. B. Diarrheagenic Escherichia coli. Clin; Microbiol; Rev., v.11, p.142-201, 1998.

NGUYEN R.N.; TAYLOR L.S.; TAUSCHEK M.; ROBINS-BROWNE R.M. Atypical enteropathogenic Escherichia coli infection and prolonged diarrhea in children. Emerg. Infect. Dis., v.12, p. 597-603, 2006.

O'BRIEN A.O; LIVELY T.A; CHEN M.E; ROTHMAN S.W; FORMAL S.B. Escherichia coli O157:H7 strains associated with haemorrhagic colitis in the United States produce a Shigella dysenteriae 1 (SHIGA) like cytotoxin. Lancet, v. 26, p.702, 1983.

ROCHA L.B.; PIAZZA R.M. Production of Shiga toxin by Shiga toxin-expressing Escherichia coli (STEC) in broth media: from divergence to definition. Lett. Appl. Microbiol., v. 45, p. 411-417, 2007. 
SCALETSKY, I. A.; FABBRICOTTI, S. M.; SILVA, S. O. C.; MORAIS, M. B.; FAGUNDES-NETO, U. HEp-2-Adherent Escherichia coli strains associated with acute infantile diarrhea, São Paulo, Brazil. Emerg. Infect. Dis., v. 8, p. 855-58, 2002 .

SCHMIDT H.; MAIER E.; KARCH H.; BENZ R. Pore-forming properties of the plasmid-encoded hemolysin of enterohemorrhagic Escherichia coli O157:H7. Eu.r J. Biochem., v. 15, p. 594-601,1996.

STUDIER, F. W. Analysis of bacteriophage T7 early RNAs and proteins on slab gels. J. Mol. Biol., v. 79 p. 237-248, 1973.

SUTTORP, N.; FLÖER, B.; SCHNITTLER, H.; SEEGER, W.; BHAKDI, S. Effects of Escherichia coli hemolysin on endothelial cell function. Infect. Immun., v.58, p. 3796-3801, 1990.

TORRES A.G.; TUTT C.B.; DUVAL L.; POPOV V.; NASR A.B.; MICHALSKI J.; SCALETSKY I,C. Bile salts induce expression of the afimbrial LDA adhesin of atypical enteropathogenic Escherichia coli. Cell Microbiol,, v. 9, p.1039-1049, 2007.

TRABULSI, L.R., KELLER, R., TARDELLI GOMES, T.A. Typical and atypical enteropathogenic Escherichia coli. Emerg. Infect. Dis,, v. 8, p. 508-513, 2002.

TOBE, T.; HAYASHI, T.; HAN, C.G.; SCHOOLNICK, G.K.; OHTSUBO, E.; SASAKAWA, C. Complete DNA sequence and structural analysis of the enteropathogenic Escherichia coli adherence factor plasmid. Infect. Immun., v. 67, p. 5455-5462, 1999.

TOWBIM, H.; STAEHELIN, T.; GORDON, J. Electrophoretic transfer of proteins from polyacrilamide gels to nitrocellulose sheets: procedure and some applications. Pro Natl Acad Sci., v. 76, p. 4350-4354, 1979. 
VIDAL J.E., CANIZÁLEZ-ROMÁN A., GUTIÉRREZ-JIMÉNEZ J., NAVARROGARCÍA F. Molecular pathogenesis, epidemiology and diagnosis of enteropathogenic Escherichia coli. Salud Publica Mex., v. 49(5), p. 376-86, 2007.

VIEIRA, M.A.M.; ANDRADE, J.R.C.; TRABULSI, L.R.,;ROSA, A.C.P.; DIAS, A.M.G.; RAMOS, S.R.T.S.; FRANKEL, G.; GOMES, T.A.T. Phenotypic and genotypic characteristics of Escherichia coli strains of non-enteropathogenic $E$. coli (EPEC) serogroups that carry eae and lack the EPEC adherence factor and Shiga toxin DNA probe sequences. J. Infect. Dis., v. 183, p.762-772, 2001.

VILHENA-COSTA A.B.; PIAZZA R.M.; NARA J.M.; TRABULSI L.R.; MARTINEZ M.B. Slot blot immunoassay as a tool for plasmid-encoded toxin detection in enteroaggregative Escherichia coli culture supernatants. Diagn. Microbiol. Infect. Dis., v.55, p.101-106 2006.

WANI, A. S.; NABI, A.; FAYAZ, I.; AHMAD, I.; NISHIKAWA, Y.; QURESHI, K.; KHAN, A. M.; CHOWDHARY, J. Investigation of diarrhoeic faecal samples for enterotoxigenic, Shiga toxin-producing and typical or atypical enteropathogenic Escherichia coli in Kashimir, India. FEMS Microbiol. Lett., v. 261 p. 238-244, 2006.

WELCH, R A. Pore-forming cytolysins of Gram negative bacteria. Mol. Microbiol., v.5, p.521-528, 1990.

WELCH, R. A.; HULL, R.; FALKOW, S. Molecular cloning and physical characterization of a chromosomal hemolysin from Escherichia coli. Infect. Immun., v. 42, p. 178-186, 1983.

YATSUNAGI, J.; SAITO, S.; SATO, H.; MIYAJIMA, Y.; AMANO, K.; ENOMOTO, K. Characterization of enteropathogenic and enteroaggregative Escherichia coli isolated from diarrhea outbreaks. J. Clin Microbiol., v.40, p.294-297, 2002. 